\title{
Failure to respond to a coral disease epizootic in Florida: causes and consequences
}

\author{
William Precht' \\ I Dial Cordy and Associates, Inc., Miami, USA \\ Corresponding author: William Precht (william.precht@gmail.com)
}

Academic editor: C. Harrod | Received 7 July 2020 | Accepted 29 December 2020 | Published 20 January 2021

Citation: Precht B (2021) Failure to respond to a coral disease epizootic in Florida: causes and consequences. Rethinking Ecology 6: 1-47. https://doi.org/10.3897/rethinkingecology.6.56285

\begin{abstract}
Stony coral tissue loss disease (SCTLD) was first observed in September 2014 near Virginia Key, Florida. In roughly six years, the disease spread throughout Florida and into the greater Caribbean basin. The high prevalence of SCTLD and high resulting mortality in coral populations, and the large number of susceptible species affected, suggest that this outbreak is one of the most lethal ever recorded. The initial recognition and management response to this catastrophic disease in Florida was slow, which delayed the start of monitoring programs and prevented coordinated research programs by at least two years. The slow management response was a result of several factors that operated concurrently.

First, the Port Miami dredging project was ongoing during the coral disease epidemic and dredging rather than SCTLD was blamed by some managers and local environmental groups for the extreme coral losses reported in the project's compliance monitoring program. Second, this blame was amplified in the media because dredging projects are intuitively assumed to be bad for coral reefs. Third, during this same time State of Florida policy prohibited government employees to acknowledge global warming in their work. This was problematic because ocean warming is a proximal cause of many coral diseases. As a result, the well-known links between warming and coral disease were ignored. A consequence of this policy was that the dredging project provided an easy target to blame for the coral mortality noted in the monitoring program, despite convincing data that suggested otherwise.

Specifically, results from the intensive compliance monitoring program, conducted by trained scientific divers, were clear. SCTLD that was killing massive numbers of corals throughout Florida was also killing corals at the dredge site - and in the same proportions and among the same suite of species. While eradication of the disease was never a possibility, early control measures may have slowed its spread or allowed for the rescue of significant numbers of large colonies of iconic species. This coral disease outbreak has similarities to the COVID-19 pandemic in the United States and there are lessons learned from both that will improve disease response outcomes in the future, to the benefit of coral reefs and human populations.
\end{abstract}

Copyright William Precht This is an open access article distributed under the terms of the Creative Commons Attribution License (CC BY 4.0), which permits unrestricted use, distribution, and reproduction in any medium, provided the original author and source are credited. 


\section{Keywords}

Disease, Caribbean, Coral Bleaching, Coral Reefs, COVID-19, SCTLD, Response

\section{Introduction}

Imagine that you live in an apartment building, and a dozen of your neighbors became sick, then died. You live on the top floor, and those who initially fell ill were on the first floor, then a week later a few people on the second floor went out the door in ambulances, and shortly after whatever was killing your friends jumped several stories to just below where you lived. At the same time, you noticed ambulances across the street and down the block. How would you feel knowing that whatever was killing your neighbors was coming for you? And no matter what you did, including calls to your doctor, local government officials, and all your friends, nothing happened. It was like you were in a bad dream. Where was the yellow police tape to identify danger zones? Why wasn't this blowing up the Internet? Where was the official government response? Why was the Center for Disease Control (CDC) quiet? The thing is, this describes exactly what happened to coral reefs in southeast Florida starting in 2014 (Precht et al. 2016) and also during the early months of the COVID-19 pandemic in the United States in 2020 (Morgan and Wang 2020). As coral reef scientist this was my worst nightmare.

Importantly, similar to human pandemics, in the case of coral ecosystems, this wasn't the first time we witnessed such an event; scientists and managers had more than three decades to prepare for this latest coral disease epidemic, with plenty of signs that it was coming (Hayes and Goreau 1998; Aronson and Precht 2001; Cróquer et al. 2005; Miller et al. 2009; Rogers et al. 2009; Hoegh-Guldberg and Bruno 2010; Miller and Precht 2013). Yet, nothing changed. By analogy, we knew exactly what to do when COVID-19 appeared (NCTC 2016 ; NSC 2016) but in the United States we failed miserably (Livingston 2020; Orcutt 2020; Schneider 2020; Zenko 2020). However, other countries were extremely proactive in attacking the COVID-19 pandemic, implementing early testing and contract tracing that led to quarantining infected populations as well as mandatory stay-at-home orders, social-distancing measures, and the wearing of facial coverings (Lee et al. 2020; Leonhardt 2020; Lu et al. 2020; McGregor 2020; McNeil 2020). These early actions slowed the rate spread, reduced hospitalizations, and most importantly limited the mortality from this highly contagious virus (Morgan and Wang 2020). Why did the United States lag behind these other nations in implementing a rapid, thorough response, and what were the consequences to this response? And is it possible that the same failures we saw in COVID-19 explain the lack of response to SCTLD? The goal of this review is to identify lessons learned from these disease events to foster improved response times in the future, to benefit both coral reefs and human populations. 


\section{The outbreak}

In the fall of 2014, while surveying corals for compliance monitoring associated with the Port Miami deepening project, scientific divers from the environmental consulting firm Dial Cordy and Associates, Inc. (DCA) identified the first signs of a coral disease outbreak at one of their far-field control monitoring sites off Virginia Key, FL (DCA 2015a, b, 2017; Precht et al. 2016, 2019; Gintert et al. 2019). This site was located less than $250 \mathrm{~m}$ from the Miami Central District Municipal Wastewater Treatment Plant's discharge pipe trench that was found to be leaking (Staletovich 2017).

While individual corals with disease signs had been noted as early as 2013, disease prevalence exceeding 5\% was not observed until late September 2014 (Figure 1). The outward signs of this disease were similar to reports of white-plague disease that was originally described in the Florida Keys in the mid-1990's by Richardson et al. (1998a, b). This earlier disease spread through the reefs in the northern portion of the Florida Keys National Marine Sanctuary (FKNMS) and killed millions of corals (Sokolow et al. 2009). The new disease outbreak, now known as stony coral tissue loss disease or SCTLD for short (FKNMS 2018) began just as corals were starting to regain their color (zooxanthellae) following a warm-water, mass coral-bleaching event observed throughout the region during the summer of 2014 (NOAA 2014; Manzello 2015).

Observations made throughout Miami-Dade County in the fall of 2014 and through the first half of 2015 by Precht et al. (2016), discovered that the deadly epidemic was much more widespread than documented by the Port Miami compliance monitoring program. No one knew at the time that we were witnessing the onset of one of the most contagious and deadly coral diseases ever recorded. Based on personal observations that noted the rapid spread and extremely high levels of mortality, Precht sent an email on November 20, 2014 to more than 20 local scientists, colleagues, regulators, and managers that highlighted the potential impact of this disease. At this point the reality of the SCTLD outbreak started to resemble a nightmare.

Initially, Precht received little response to his email. However, concurrently and coincidentally, Dr. Diego Lirman, Dr. Laurie Richardson, and Dr. Mauricio RodriguezLanetty had anticipated the possibility of disease outbreak(s) associated with warming and the 2014 bleaching event and had written a Rapid Grant proposal to the National Science Foundation (NSF) entitled "A hyper-thermal anomaly in the Florida Reef Tract: An opportunity to explore the mechanisms underpinning patterns of coral bleaching and disease" which was awarded to Mauricio Rodriguez-Lanetty from the Biological Oceanography section of NSF, Award \#1503483. In addition, Ms. Karen Bohnsack from the Florida Department of Environmental Protection (FDEP) was collecting periodic updates of disease reports from the Southeast Florida Action Network (SEAFAN) BleachWatch program and posting these on the SEAFAN website (https://floridadep.gov/rcp/ $\mathrm{coral} /$ content/bleachwatch). Coordination with these scientists as well as conversations with local recreational dive operators helped track the spread of this disease outbreak region-wide (see Precht et al. 2016). Thus, the initial response to this disease outbreak 


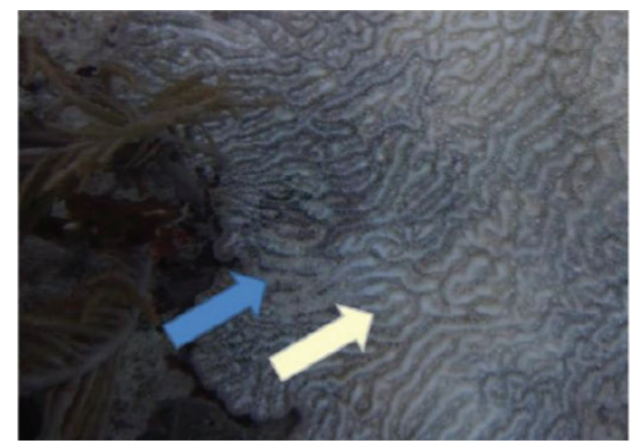

September 26, 2014

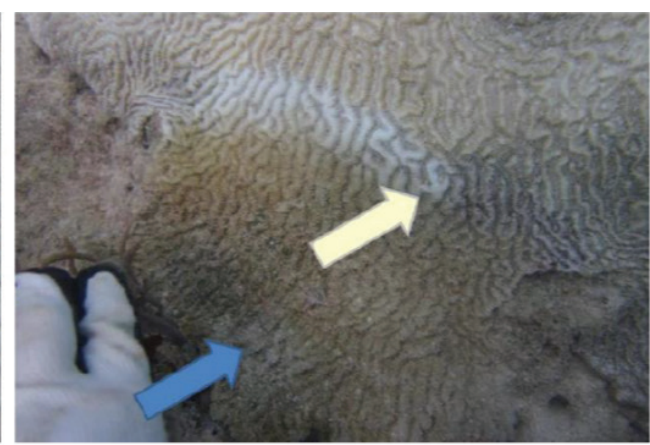

October 8, 2014

Figure I. Close-up of initial observation of partial mortality (blue arrow) and first appearance of the white disease line (light yellow arrow) from tagged Meandrina meandrites coral located at one of DCA's southern, inner-reef, far-field control permit compliance monitoring sites associated with the Port Miami deepening project (coral tag number R2SC2-LR-T2-C1) on September 26, 2014 (left). The initial field code for this coral was "UC" for unknown condition. However, a well-defined SCTLD disease line (light yellow arrow) and continued partial mortality from initial location of mortality (blue arrow) was observed on October 8, 2014 (right) confirming the disease (from Precht et al. 2019). Note that in the photo on right, that the bleached portion of the colony has regained color (zooxanthellae) in response to cooler water temperatures only 12 days later. Also note the rapid colonization of turf algae on the recently killed portions of the colony (blue arrow) and the line of active disease (yellow arrow).

was defined by a fortuitous NSF study (Merselis et al. 2018) and ad hoc observations made by local scientists and concerned citizens (Peters and Fogarty 2016). In other words, some monitoring and sampling were being conducted, however, there was essentially no coordinated management response to do anything about the spread of the emerging killer disease, despite the existing capacity to rapidly organize a multi-agency response through the Florida Reef Resilience Program (http://frrp.org/\#).

In 2015, as the disease was ravaging the coral populations throughout the waters of Miami-Dade County, Precht continued to send numerous emails including copies of photographs and the data his team were collecting to inform other colleagues of these catastrophic observations. However, more than six-months after Precht's initial email, a trail of older emails responding to Precht's first observations surfaced. It appeared that regulators who had received Precht's initial emails were reluctant to respond because they thought the coral mortality he was reporting was caused and/ or exacerbated by an on-going dredging operation at Port Miami, and that if it was a disease it was restricted to an area only surrounding Port Miami. Thus, the prevailing thought was that the disease outbreak was a 'local' issue that was likely caused by irresponsible environmental stewardship (Staletovich 2015a). The evidence for this conclusion was based on assumptions and biases that are typical of environmental organizations that often mean well but may also have agendas (see Silverstein 2014; Miami Waterkeeper 2019, 2020). These claims made splashy headlines and raised the profile of the Port Miami project (Silverstein 2015). Assumptions, however, can lead to accusations, and describe the motis operandi of some NGO's and conservation 
organizations (Grigg and Dollar 1995; Butler 2009; Zeller 2017; Corry 2018), that include personal attacks on scientists that publish contrary views (see Lewandowsky 2011; Hathaway 2016; Lutcavage 2016), and also forms a significant portion of their fundraising campaigns, many of which are based on nusciance law suits (Schwartz 1991; Grigg and Dollar 1995; NRR 2009; CNR 2012; Miller 2015; PTH 2020). However, this strategy should not also arise from government stewards who by default are required to base their conclusions on facts and data and not speculation or personal biases (Finkl and Kruempel 2005; Kuehn 2015).

The email trail that emerged during this period was troubling. In one specific case, a State of Florida employee and program administrator stated the following in an email entitled "White Plague Coral Disease Outbreak in Miami" dated July 1, 2015: "I am admittedly biased in my presumption that new(ish) sediment in the system is in part or wholly triggering this event. I would like to discuss what (if anything) we might be able to do to collect useful data that we can use to prove...my (biased) presumption." The words highlighted in parentheses are her own. This is an astonishing admission. It's like if in my nightmare of disease ravaging my neighborhood, that the government official responsible for protecting our health and safety believed that the epidemic, without any evidence, was intentionally caused, spread, and then covered-up by another country (Quinn 2020). Yes, in the real-world fact is often stranger than fiction. Even more unsettleing, however, this was not the first time this state employee took a position against dredging projects in southeast Florida (see Walker et al. 2012).

During the early stages of SCTLD, opponents to the Port Miami project questioned some of the original results presented in the DCA compliance-monitoring reports (DCA 2015a, b), especially the level of coral mortality associated with the disease. In fact, these DCA reports were the first documents that noted and discussed the extreme levels of coral mortality associated with this new disease. However, in trying to conflate the regional disease outbreak with the dredging project, a local NGO stated that "The Corps' report misleadingly and conveniently blames the disease and warm temperatures for the destruction of our corals..." (Staletovich 2016a). What is now evident is that the disease outbreak was real, and its impacts on the regional stony coral populations throughout southeast Florida were catastrophic. Importantly, the DCA reports were designed to capture the impacts of the dredging project and fortuitously because of the way the monitoring was conducted, the project also captured coral mortality associated with this contemporaneous region-wide disturbance (see DCA 2015a, b, 2017; Gintert et al. 2019; Precht et al. 2019). Ironically, because the NGO responsible for these comments campaigned to protect coral reefs in Florida against dredge projects (Miami Waterkeeper 2019), their effort to highlight dredging rather than SCTLD as a primary coral killer may have helped shape public opinion to minimize disease impacts at a time when the epidemic was raging (Silverstein 2015).

Starting in the summer of 2015, other scientific teams who were collecting data at their long term monitoring sites throughout the region, including at sites far from the dredging project, also reported that the levels of devastation wrought by this coral killer were significant (CSI 2016; DERM 2016; Gilliam et al. 2015, 2016; Sinigalliano et al. 2019). Their results essentially mirrored the results presented in the DCA reports 
(2015a, b) and in Precht et al. (2016). For instance, as part of the July 2015 email trail discussed above, an employee from the Miami-Dade County Department of Environmental Resource Management stated the following "yes, there is a serious disease outbreak in Miami-Dade County wiping out Dichocoenia, Meandrina, Diploria/Pseudodiploria, and Montastraea cavernosa. Most of our work has been south of Government Cut recently and into the north end of BNP (and yes, we saw it there). In most cases we only see a few colonies with active disease and numerous dead colonies... I haven't noticed any unusual sediment on the reefs where I've noticed the disease. I am also deeply concerned to see such a dramatic loss in a short window. We've been monitoring some the corals relocated from the outer reef where Government Cut was widened to about 1500' south. Based on a quick tally, 18 of the 71 transplanted colonies (25\%) and 9 out of the 31 control colonies (31\%) suffered complete mortality. All were healthy at the last monitoring in December" (for a final analysis of these tagged coral data see DERM 2016; see also CSI 2016).

In August of 2015, The US Army Corps of Engineers (USACE; sponsor of the Port Miami dredge project) asked DCA management to give a 'lesson's learned' presentation to NOAA-National Marine Fisheries Service (NMFS) regarding the impacts of both the project and the disease on the local coral communities. During DCA's presentation on August $24^{\text {th }}$, Precht specifically detailed the catastrophic observations he and his team had made throughout Miami-Dade County starting in the fall of 2014 regarding the impacts associated with this regional conflagration. NMFS staff at the meeting noted they were unaware of the 'significant impact this disease was having regionwide' and asked Precht if he could provide them with the data collected outside of the purview of the Port Miami Project (which was at the time still unpublished) to help bring them up to speed on this issue. At that presentation, Precht noted the fact that he had provided staff of NMFS, via numerous emails with photographs, the extent of the disease throughout the waters of Miami-Dade County, this included his original email noted above which dated back to November 20, 2014.

Interestingly, just three days after the DCA presentation to NMFS, on August $27^{\text {th }}$, the FDEP-Coral Reef Conservation Program organized an 'emergency' conference call on August $28^{\text {th }}$ with various local and regional stakeholders (including the NMFS) to discuss the importance of this 'new' disease outbreak (Table 1). This emergency call was initiated more than nine months after Precht first notified NMFS, the FDEP, and others of the impending disaster associated with this coral disease epizootic. Does nine months to respond seem like a long time? Is this amount of time typical for how government agencies respond to emergencies on coral reefs in Florida? No. For example, the Florida Reef Resilience Program, a consortium comprised of Florida scientists and resource managers from various universities, government agencies and NGOs was specifically organized to conduct rapid-response surveys. An example of their work includes a month-long survey of 76 reefs sites from Martin County to Key West, both during and shortly after an extreme winter cold front in January of 2010 that caused widespread coral mortality (Lirman et al. 2010). A similar effort was mounted in the Florida Keys immediately after the passage of Hurricane Irma in the fall of 2017. So, the answer to this question is not debatable. 
Table I. Disease response timeline for SCTLD in southeast Florida.

- $\quad$ September 26, 2014 - DCA divers note first signs of significant coral disease outbreak off Virginia Key - identified at southern innerreef far-field control monitoring site associated with Port Miami Deep Dredge Project (and adjacent to leaking Central Miami-Dade Wastewater Plant outfall pipe trench)

- November 20, 2014 - Precht notifies numerous agencies and coral scientists via email regarding disease outbreak off Virginia Key, FL and that it was spreading rapidly both north and south

- April 30, 2015 - Baker Coral Conservation Lab at RSMAS/Univ. Miami posts observations and photos of extensive coral disease outbreak at Emerald Reef in southern Miami-Dade County, FL on Facebook

- $\quad$ August 24, 2015 - Precht gives presentation to NOAA-NMFS regarding catastrophic impacts of the disease throughout MiamiDade County observed during the Port Miami expansion environmental compliance monitoring program

- $\quad$ August 28, 2015 - First Inter-Agency /Southeast Florida Stakeholder conference call as a response to mounting disease reports regionwide

- November 16, 2015 - DCA submits Port Miami post-construction analysis reports to USACE that also details the catastrophic impact of the regional coral disease

- $\quad$ May 18, 2016 - Precht gives presentation regarding lessons learned from Port Miami monitoring program highlighting impacts of regional coral disease to the South Florida Association of Environmental Professionals (SFAEP)

- $\quad$ July 7, 2016 - First Florida Reef Tract Disease coordination meeting and conference call

- $\quad$ August 10, 2016 - Precht et al. (2016) Scientific Reports manuscript regarding 'unprecented disease outbreak' is published on-line

- $\quad$ August 19, 2016 - FDEP organizes second Florida Reef Tract-Wide coordination call

- $\quad$ August 27, 2016 - Precht sends email notice to NOAA's Coral-List with an update on the status of the disease in southeast Florida

- July 11, 2017 - US Coral Reef Trask Force declares disease 'emergency' for South Florida almost three-years after disease onset and one-year after Scientific Reports manuscript was published (USCRTF meeting held in Fort Lauderdale, FL)

- July 2017 - The first signs of active disease was observed along the Jamaican north coast. This is the first sighting of disease with similar signs observed in the Caribbean

- July 24-25, 2017 - First Emergency South Florida Coral Disease Workshop is held in Florida Keys

- November 6-8, 2017 - FDEP \& FWC staff hold workshop regarding Intervention methodologies and priority sampling plan for coral disease sites in Florida

- $\quad$ February 18, 2018 - Sen. Bill Nelson of FL writes formal letter requesting Federal agencies to 'urgently' address coral disease crisis affecting Florida's reefs

- July 2018 - the Florida Department of Environmental Protection (FDEP), the Florida Keys National Marine Sanctuary (FKNMS), and the NOAA Coral Reef Conservation Program (CRCP) hosts a coral disease workshop to develop a response plan for the ongoing coral disease outbreak in Florida, with a focus on identifying interventions that could help slow the continued spread of the disease and save priority corals

- September 6, 2018 - Florida Reef Tract Coral Disease Outbreak Coordination Meeting \#12. Disease is renamed 'stony coral tissue loss disease' (SCTLD)

- $\quad$ October 2, 2018 - Publication of Case Definition: Stony Coral Tissue Loss Disease (SCTLD) by FKNMS

- December 2018 - Two sessions on SCTLD at Coral Restoration Consortium, Reef Futures Meeting, Key Largo, FL

- $\quad$ February 22, 2019 - NOAA-CRCP and MPAConnect develop a guide for managers to detect SCTLD

- $\quad$ April 2019 - AGRRA develops SCTLD disease page and tracking map on their website

- $\quad$ August 1-2, 2019 - Gulf Caribbean Fisheries Institute (GCFI) holds SCTLD Workshop in Key West, FL

- September 9, 2019 - US Coast Guard releases a bulletin outlining BMPs for ballast water exchange regarding the SCTLD outbreak

- $\quad$ November 24, 2020 - NOAA publishes 'Strategy for Stony Coral Tissue Loss Disease Response and Prevention'

- 2021 - NOAA to develop a multi-year 'Implementation Plan' that will outline a detailed course of action for SCTLD response and prevention

What is inexplicable, however, is that it wasn't for another year, until July 7, 2016 that the calls were expanded to include scientists, regulators, and resource managers from throughout the entire region (Table 1). Two years passed and by then SCTLD had now moved south through Biscayne National Park and into the FKNMS (Table 2). If nine months is too long, then two years clearly crosses the line. On the other hand, researchers could now predict the rate of progression of the disease with relative certainty (Precht et al. 2016; Muller et al. 2020) and each new reef impacted followed the same general pattern of disease prevalence, species susceptibility, and subsequent mortality as described in Precht et al. (2016) (e.g. Lunz et al. 2017; Neely 2018; Sharp et al. 2019). 
Table 2. Reports of SCTLD spread across Florida and the Caribbean (2014-2020).

\begin{tabular}{l}
\hline Fall 2014 Isolated sites with significant coral disease were reported near Virginia Key (Miami-Dade County). \\
\hline Summer 2015 Disease had spread both north and south throughout Miami-Dade County and into Broward County \\
Fall 2015 Widespread disease was confirmed in southeast Florida as far north as Pompano Beach and south throughout Biscayne \\
National Park and to northernmost Key Largo. \\
Summer 2016 The disease continued to spread in southeast Florida north throughout Palm Beach County and to the south into the \\
Upper Florida Keys. \\
Spring 2017 Reports of widespread disease were confirmed as far north as St. Lucie Inlet in Martin County and to the southern \\
boundary of the Upper Florida Keys. \\
Summer 2017 The disease continues to migrate south in the FKNMS and was also first observed along the north coast of Jamaica. \\
This is the first report from the Caribbean. \\
\hline Spring 2018 The disease continues to migrate south through the FKNMS and into the Lower Florida Keys. Disease common along \\
Jamaican north coast. \\
\hline Summer 2018 Signs of disease were reported in the Mexican Caribbean (Yucatan). \\
Fall 2018 Disease corals were discovered in St. Maarten. \\
\hline Winter $2018-2019$ The disease outbreak reached beyond Key West, and disease signs were reported in St. Thomas, USVI. First reports \\
of disease in South Caicos, Turks \& Caicos Islands \\
\hline Spring 2019 Disease observed in the Dominican Republic and Turks \& Caicos. \\
\hline Summer 2019 Disease along the Meso-American Reef Tract progresses south along the Yucatan peninsula and is detected in northern \\
Belize. \\
\hline Summer 2019 Disease discovered in St. Eustatius. Disease continues to spread west along the Florida Reef Tract to the Marquesas Keys. \\
\hline Winter 2019-2020 Disease reported in St. John, USVI, Culebra, Puerto Rico, and Grand Bahama Island, Bahamas. \\
\hline Spring 2020 Disease reported in the British Virgin Islands add along the north coast of Puerto Rico. \\
\hline Summer 2020 Disease detected in St. Croix, USVI, New Providence, Bahamas, Guadeloupe, Grand Cayman, and St. Lucia. \\
\hline Fall 2020 Disease reported on Lighthouse Reef, Belize and throughout the reefs of Roatán, Honduras \\
\hline
\end{tabular}

So, why was there a failure by managers to respond rapidly to this disease outbreak? And is there anything that could have been done that would have saved corals? The two questions are related because the delay impacted the ability to effectively respond to the disease event. It is apparent that there was tremendous opposition to the Port Miami dredging project even before it started (Alverez 2011). This included lawsuits promulgated by local NGO's against the USACE (Solomon et al. 2011; Miller 2012; The Maritine Executive 2012), as well as extremely biased local media coverage of the project (Staletovich 2014a, b), Thus, opponents to the Port Miami project (including government employees from NOAA-NMFS and the State of Florida) immediately turned to the dredging project (Nelson 2015; Staletovich 2015a, b) as the probable cause for the coral mortality without investigating alternative explanations (Plowright et al. 2008; Gintert et al. 2019). For instance, in a letter dated September 11, 2015 from Roy Crabtree, Southeast Regional Administrator for the NMFS to Col. Jason A. Kirk, the Commander of Jacksonville District of the USACE stated the following "... the presentation delivered by DCA on August 24, 2015, NMFS believes coral disease is overemphasized as the singular cause of coral impacts." As for 'overemphasizing' the effects of this disease, however, NOAA (2020) has recently noted "The SCTLD panzootic... is unprecedented in scale, duration, and rate of associated coral mortality for susceptible coral species." Therefore, the impact of this disease cannot be overstated. Yet, their conclusions (based on assumptions and not data) was that the impact of the epidemic was overstated. Ironically, at the time of the Crabtree letter in the late summer of 2015, DCA had observed a mortality of about $20 \%$ of the tagged corals at the Port Miami monitoring sites associated with the disease (DCA 2015a, b). However, the disease contuned to ravage the coral communities throughout 
Miami-Dade County for the next 12-18 months ultimately resulting in a net loss of > $30 \%$ to the total coral population (Walton et al. 2018; Hayes 2019; Precht et al. 2019).

Equally problematic, five years after the initial observations were recorded of this catastrophic coral killer (Precht et al. 2016), the same state agency that originally blamed the dredging project for initiating the disease funded an effort directed at proving that the Port Miami (POM) dredging was responsible for the initiation and spread of the disease (Dobbelaere et al. 2020). Specifically, Dobbelaere et al. (2020) stated "[T] he objective of this study is to use virtual backtracking to identify the source of infectious material driven by currents that might have initiated the SCTLD outbreak on the reefs identified by Precht et al. (2016). These backtracking simulations are complemented with sediment transport simulations in order to assess the effect of the dredging activities conducted during the expansion of the POM."

A significant problem with claims or assumptions that the dredging project was the cause of the disease epidemic was that the people who were talking about the dredge project killing the corals rarely, if ever, went in the water to see what was actually happening. Even worse, when they did go diving, they conducted single surveys often long after the corals had died and without baseline data and controls for comparison (NMFS 2015, 2016). These post hoc impact surveys are not analogous to doing an autopsy where you can run chemical tests or make observations that confirm the cause of death. Corals generally do not retain that kind of information. You have to be present, in near real-time, to observe what killed the corals. If not, then you can only guess about the cause of death. In other words, you cannot write a meaningful death certificate when all you have is an old dead skeleton. Similar examples abound in the conservation sciences where surveys that are performed without adequate controls or baselines lead to inaccurate conclusions (i.e. Hance 2013).

Writing coral death certificates is especially difficult these days because there are so many damaging things happening in our offshore waters, none of which are good for corals (Precht and Miller 2007). This includes, but is not limited to, widespread warming and temperature stress that causes coral bleaching (McWilliams et al. 2005; Manzello 2015), chronic and low-level exposure to pollutants (Dubinsky and Stambler 1996; Bojko et al. 2020), nutrients (Vega Thurber et al. 2014), and wastewater (Wear and Vega Thurber 2015) including leaking septic system drain fields, and storm water runoff (Malella 1998; Finkl and Charlier 2003) as well as direct release of secondary treated wastewater into the Atlantic Ocean through outfall pipes (Staletovich 2017; Staley et al. 2017). And yes, in many cases, coastal development including dredging projects (Foster et al. 2010; Erftemeijer et al. 2012).

To emphasize why single surveys that observe corals only after they are dead can often lead to incorrect conclusions; the following example is enlightening. The photo below (Figure 2) was taken by a contract employee of NOAA-NMFS while shadowing one of DCA's project team divers during one of their site visits on May 19, 2015. The figure caption in their NMFS (2015) field report reads as follows "Figure 5a. Likely colonies of Meandrina meandrites smothered by fine sediment from the Port of Miami expansion dredging. Note that species identification after burial is complicated, however the morphology of the ridges and septa are distinct to M. meandrites." Importantly, this was a tagged 


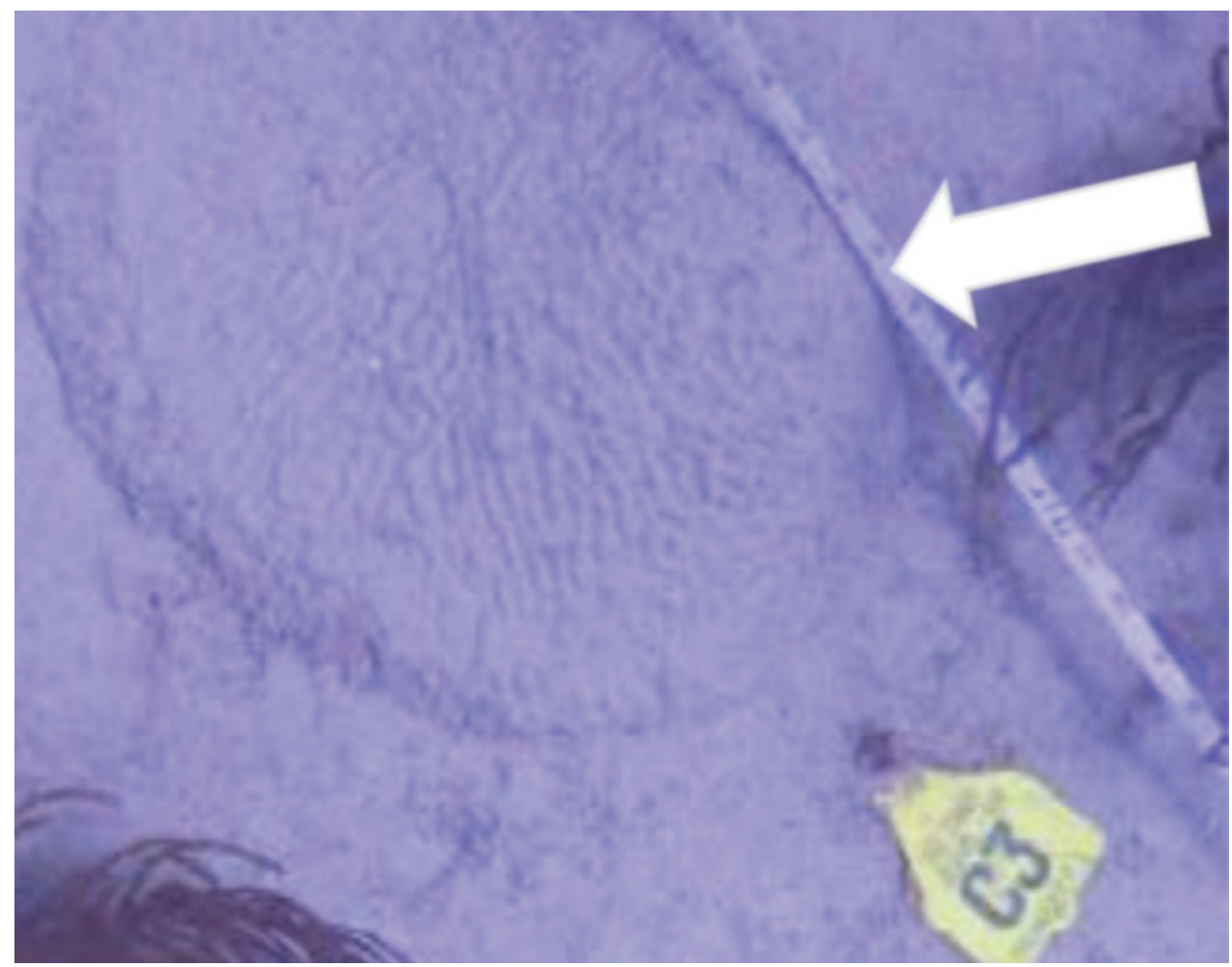

Figure 2. Image taken from Figure 5a in NMFS report (NMFS 2015). This tagged colony was coral number 3 on transect 1 at site R2N1-RR (located on an Inner Reef site and approximately 10 meters of the active dredge channel). Compare this photo with montage shown in our Figure 3 below of the same tagged coral. Diver from NMFS wafted sediment off top of colony by hand to reveal skeletal features prior to taking this photograph. Photo taken on May 19, 2015. If you only had this photo, how could you determine the cause of mortality?

coral in DCA's long-term compliance monitoring program. As a result, DCA scientists could reconstruct the history of this colony by observing the sequence of photos taken in the weeks and months before the NMFS site visit. Dozens of dives were made to reconstruct the history of corals at the site, not just one after the coral had died as was done by the NOAA-NMFS diver. First, the coral in the photograph is actually a colony of Pseudodiploria strigosa and not $M$. meandrites. So, the NOAA contract employee misidentified the species of coral. While trying not to read too much into the mistake, this suggests that the person doing the survey was perhaps not sufficiently experienced to understand that appearance can be deceiving. Indeed, a detailed photo montage of the coral documented the history of this colony during the dredging project and unambiguously documents the ultimate cause of its mortality as SCTLD (see Figure 3).

The mortality of this coral was caused by SCTLD that initiated following a regional thermal stress (bleaching) event and not sediment burial as proffered in the NMFS (2015) report. Unfortunately, the postmortem observations by NGOs, government 

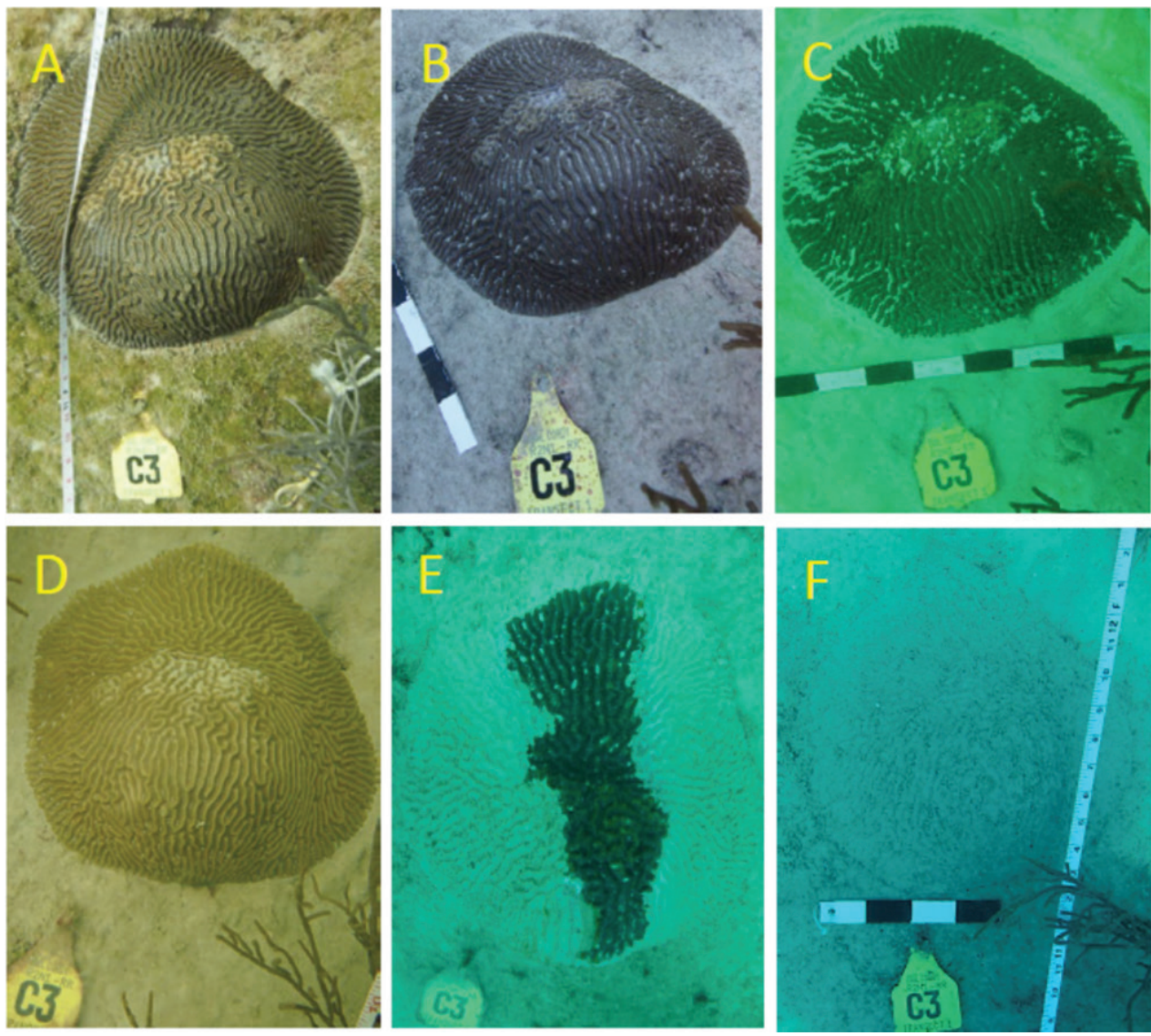

Figure 3. Temporal photographic montage of Pseudodiploria strigosa colony (Tagged colony R2N1RR-T1-C3). This is the same channel-side coral as depicted in Figure 2 above. A Photograph of coral during initial baseline surveys on October 21, 2013 B coral during baseline week 4 on November 18, 2013 just days prior to initiation of dredge activities. Note the green covering of turf algae visible in previous photo is now covered in fine-grained sediment as a result of the passage of the first winter storm of the season C coral during compliance week 30 on June 14, 2014 showing sediment stress and partial burial from dredging activities with a berm of sediment around base of colony. This photo represents the week of maximum sediment stress to corals at this site during the peak of dredging operations $\mathbf{D}$ coral showing signs of bleaching (paling) associated with warm-water thermal anomaly during compliance week 45 on September 28, 2014, note no apparent lesions or mortality related to earlier sediment stress event E colony showing $>60 \%$ mortality associated with progression of white-plague-like disease during compliance week 69, March 18, 2015; and $\mathbf{F}$ total colony mortality, note the coral is covered by fine-grained sediment, photo taken on May 19, 2015 following completion of dredging activities. This photo was taken on the same day as Figure 2 above. Note that the dead colony can no longer actively shed sediment. These photographs are accessible via a public access data base provided by the FDEP.

officials, and regulators, like the one shown above in Figure 2 above are founded only on assumptions and anecdote - not data and the facts that were accumulated during careful and repeated monitoring over time by the DCA scientific dive team. The 
NMFS field reports and a publication that resulted (NMFS 2015, 2016; Miller et al. 2016) are riddled with similar errors and assumptions that fail because correlation does not prove causation (see discussion in Precht et al. 2019). However, because of social cognitive biases (Bardon 2019), the assertions made in these NMFS letters and reports likely further entrenched regulators, NGOs and the media, and reinforced their belief that coral mortality observed near Port Miami was dredge-related and not a result of a regional, highly virulent water-borne contagion (Staletovich 2015a, b, 2016a, b; Nelson 2015; Alverez 2016; Cunning et al. 2019).

Blaming dredging on initiating or enhancing coral disease is not new, an almost identical story emerged associated with a major dredging project in Western Australia. In one case, a group did one-off post hoc surveys almost a year after the cessation of dredging activities and attributed a significant coral disease outbreak to sediment stress associated with the dredging project (Pollock et al. 2014). However, a recent manuscript by Stoddart et al. (2019) that monitored these same reefs before, during and after the dredging operation found there was no association between dredge-induced sediments and increased coral disease. Similarly, the broad and sweeping conclusions about the Port Miami project, based on single scuba dives that were also post hoc surveys (Miller et al. 2016), does little to engender confidence in understanding the role of dredging on causing or enhancing coral disease prevalence (see discussion in Precht et al. 2019).

A fair question to ask at this point is, "Why was DCA confident that SCTLD killed so many corals at the dredge site rather than sediment from the dredging project itself?' The answer is straight-forward. The DCA compliance monitoring program was the most transparent, comprehensive, and detailed assessment of factors causing coral stress and mortality ever conducted in southeast Florida. Indeed, the DCA compliance monitoring program was specifically designed by the FDEP to detect the causes of coral stress during the course of the dredging project. At the time, sediment was considered to be the biggest threat to the corals, not disease. In addition, the results of the DCA monitoring program are based on 10,850 dives conducted by trained scientific divers over a three-year period (Gintert et al. 2019; Precht et al. 2019). This compares to a handful of one-off dives that were used to write government reports and one peer-reviewed publication that are critically flawed, as described above. In addition, as part of the permit-compliance monitoring for the project (FDEP 2012), there was a requirement to tag approximately 650 corals both at impact sites and their far-field controls for repeated measures monitoring. Each of these corals $(n=643)$ was observed and photographed approximately 40 times throughout the project. That is $>$ 25,000 in situ coral observations made over the course of the 40 site visits. This level of coral monitoring had previously been unprecedented in South Florida to evaluate coral condition from a dredging project, or for that matter, any impact assessment program. Indeed, the longest running coral monitoring program in the Florida Keys, run by the Florida Fish \& Wildlife Conservation Commission (FWC), while spatially extensive, takes pictures and video only once per year (Ruzicka et al. 2013).

The coral condition data from the FDEP monitoring program were additionally compared in the lab with corresponding still photographs from each coral for cross- 
verification and validation. Combining these in situ coral data with other biotic (video functional assessments) and abiotic metrics (sediment, temperature, etc.) allowed differentiation between chronic and acute stressors and whether they were natural or anthropogenic in origin (Gintert et al. 2019). More specifically, it was possible to calculate the percentage of corals impacted by sedimentation, predation, competition, coral bleaching, and disease. Most importantly, in cases where the tagged corals had died, it was possible to discern the exact cause of mortality by carefully evaluating the sequence of events recorded (and photographed) prior to their death (see Figure 3). Not surprisingly, coral morbidity (partial mortality) associated with sedimentation was highest at sites immediately adjacent to the dredge operations with several corals actually dying directly from sediment burial (seven of the dredge-adjacent tagged colonies, $-2 \%$ ) which were attributed to project related impacts (Precht et al. 2019).

So, where do things stand today concerning resolution of the question; 'What killed most of the corals at the dredge project site, disease or dredging?' The scientific monitoring data are irrefutable (see Table 3), but the facts sometimes don't drive media headlines or public perception (NCRWN 2017). Recently, the DCA (2017) report as well as the follow-up manuscript by Gintert et al. (2019) have been misquoted in the media - specifically, Dr. Andrew Baker (co-author in Cunning et al. 2019) stated the following in a radio interview "The notion that only six corals died as a result of dredging is actually sort of absurd" (Staletovich 2019). Clearly, that is not what was said (see Townsend 2019a, b). The reports and follow-up manuscripts clearly stated that was the total numbers of channel-side corals that died in the 'tagged' coral surveys during the project that could be attributed to sediment burial. That number is $-2 \%$ of the tagged channel-side corals $(\mathrm{n}=336)$. Approximately two percent of all the channel-side corals (those within a mixing zone of about 150 meters on either side of the dredged channel) is a significant number of dead corals - not just six or seven. However, even if only one coral died from project-related sediment burial that is one too many! That is why repeated measures monitoring programs are so important to understanding the specific cause of mortality when corals die (Green and Smith 1997; Gintert et al. 2019). Only then can appropriate lessons learned from these monitoring programs be applied to future projects to further reduce or eliminate project-related impacts (Precht 2018). Scholarship is important, and getting the facts correct are equally important, especially if they influence the public perception of controversial environmental issues. Further, exaggerated, or unsubstantiated claims ultimately hinder and undermine conservation efforts (see Koh et al. 2010; Pearce 2012; Kuntz 2014; Komonen et al. 2019). Importantly, in the case of Port Miami, the field data sheets, videos and photographs collected as well as the analysis and reports prepared by DCA as part of the project are in the public domain and can be easily obtained through the USACE (https://www. saj.usace.army.mil/Missions/Civil-Works/Navigation/Navigation-Projects/MiamiHarbor-Deepening/) and the FDEP (https://floridadep.gov/south/sd-outreach/documents/using-oculus-locate-public-records).

Here's the real story. DCA's last monitoring event of the tagged corals performed in 2016 revealed that the combined losses from missing corals $(n=31)$, sediment burial 


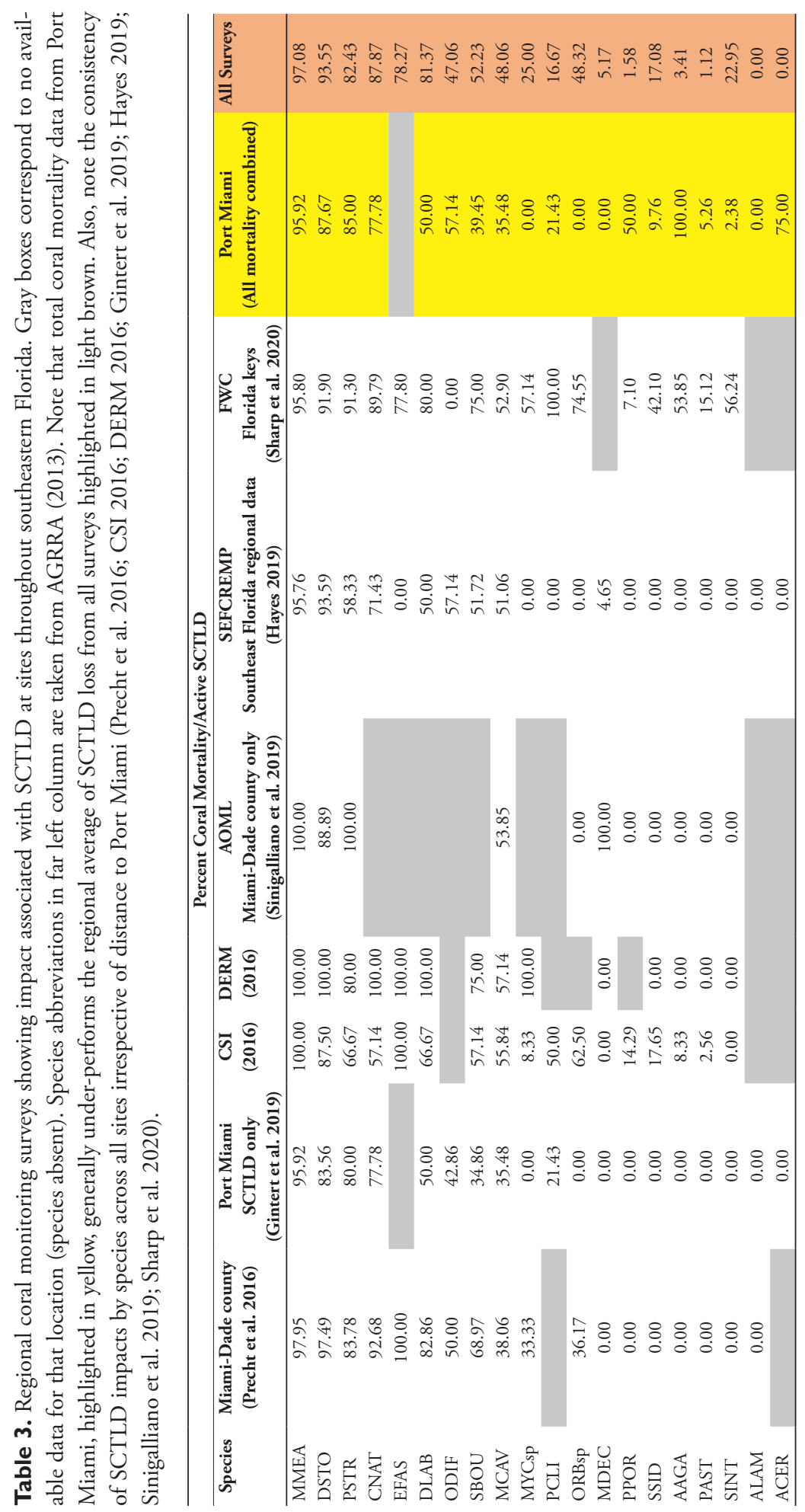


$(\mathrm{n}=7)$, coral bleaching $(\mathrm{n}=4)$, competitive mortality $(\mathrm{n}=6)$, and other factors $(\mathrm{n}=9)$ accounted for the mortality of $8.8 \%$ of all monitored corals, yet $30.2 \%(n=194)$ of all tagged corals likely died as a direct result of this disease outbreak. It should also be noted that at the time of the final DCA monitoring event in 2016, 17 of the remaining tagged colonies still had active SCTLD lesions (mostly colonies of Montastaea cavernosa and Solenastrea bournoni). If you assume these 17 corals will eventually die from SCTLD, the total impact of the disease increases to $32.8 \%(n=211)$ at the Port Miami sites. Thus, while project related impacts were real and not trivial, the devastating levels of coral mortality were caused by the regional coral disease epidemic (Gintert et al. 2019). Importantly, disease varibilty within and between sites was directly related to the composition of coral species at those locations and not distance from the dredge operations (Gintert et al. 2019). This loss of around 30\% of the coral population to SCTLD has been recorded by other scientists throughout the region (Table 3). Still, there are some scientists who are diminishing the actual impacts of this disease (Miller et al. 2016; Cunning et al. 2019) with results that are in stark contrast to the regional data (Gilliam et al. 2015, 2016, 2018; CSI 2016; DERM 2016; Precht et al. 2016, 2019; Aeby et al. 2017; Hayes et al. 2017; Lunz et al. 2017; Neely 2018; Ruzicka 2018; Walker 2018; Walton et al. 2018; Hayes 2019; Sinigalliano et al. 2019; Sharp et al. 2019, 2020; FDEP 2020; NOAA 2020). For instance, the purported levels of disease-related mortality described in Cunning et al. (2019) grossly underestimates the impact of the disease, not just locally but regionally as well. Citing Walton et al. (2018), Cunning et al. (2019) stated that "the observed declines in coral density around the Port of Miami far exceeded the regional estimate of 11.6\% decline (2013-2016) as a result of bleaching and disease." However, this is a direct misquote of Walton et al.'s (2018) regional estimate. Walton et al. (2018) explicitly stated the following "the 2014 to 2016 disease outbreak was arguably the most devastating disturbance event yet documented in the Southeast Florida coral reef tract (SEFCRT) and has altered ecosystem function to a point where recovery is greatly challenged. Our data estimates that regionally as much as $30 \%$ of coral colony density and 60\% of live tissue area was lost." Similarly, Dr. Dave Gilliam from Nova Southeastern University was also quoted stating "since appearing in South Florida in late 2014, as corals were weakened by bleaching, the disease epidemic has spread quickly. A 35 percent loss of stony coral has taken place off the South Florida coast north of the Keys, judging from the losses seen at sites we monitored" (see Fleshler 2017). Most recently, NOAA (2020) stated "while coral disease is a natural occurrence in reef environments, with a normal background disease rate of 2-3\% of the corals on the reef, the occurrence of SCTLD may result in 66-100\% prevalence, especially for highly susceptible species of elliptical star coral (Dichocoenia stokesii) and maze coral (Meandrina meandrites). According to the Florida Fish and Wildlife Commission (FWC), Florida's Upper Keys have seen greater than 40\% loss in coral cover between 2013 and 2018." If we put SCTLD in a human context we would be looking at a pathogen with lethality greater than Ebola and a contagion greater than the measles with losses resembling that of the Black Death of the Middle Ages (Raoult et al. 2013).

Thus, while I agree with Cunning et al. (2019) that the coral loss near Port Miami exceeded $30 \%$, if the regional coral loss both near and far from the Port Miami is $>30 \%$, where does the Cunning et al. (2019) regional value of $11.6 \%$ decline origi- 
nate? Even more inexplicable, however, are dramatic comments made by the Baker Lab on a Facebook post dated April 30, 2015 regarding a catastrophic disease outbreak observed on Emerald Reef in Miami-Dade County located approximately $9 \mathrm{~km}(5.6$ miles) south of the Port Miami project (Baker 2015); "Emerald Reef seemed to be recovering well from last summer's bleaching event, but recently we've noticed a dramatic increase in the prevalence of disease in a number of coral species. The affected colonies exhibit rapid tissue loss, and the brain corals, including Meandrina meandrites and Colpophyllia natans, have shown the most dramatic declines on Emerald Reef. It is now rare to see a healthy colony of either species on this reef, where they were relatively abundant. Unfortunately, we're also starting to notice these disease symptoms in other species, including Orbicella faveolata and Dichocoenia stokesii... While there is still life to be seen on this reef, the speed with which this disease seems to be moving through the corals is worrying indeed." This blog post was one of the first to highlight the catastrophic mortality associated with emergence of SCTLD in the region (Table 1). As previously mentioned Andrew Baker was a co-author of Cunning et al. (2019), so why was this key observation not even mentioned in their manuscript?

With regard to an attempt to specifically link sediment from dredging to coral mortality at the site, what was learned from the FDEP funded study mentioned earlier? Dobbelaere et al. (2020) used sediment simulation models to conclude that it was 'unlikely' that the material produced during dredging operations prior to the initiation of the disease (May-September 2014) was responsible for the disease epidemic. They specifically noted that "[T]his is confirmed by sand transport simulations that showed that southward currents during the simulated period were not strong enough to resuspend and propagate sediments." Therefore, a study that was designed to specifically test for sediment effects from dredging on coral disease mortality found no association. While Dobbelaere et al. (2020) was narrowly focused, their results were not discussed in the larger context of the existing literature (Gintert et al. 2019; Precht et al. 2019) or alternate hypotheses (Marella 1998; Finkl and Charlier 2004; Symonds et al. 2016; Staley et al. 2017; Sinigalliano et al. 2019). Notably absent were citations from the government funded Port Miami environmental permit compliance reports performed by DCA (DCA 2015a, b, c, d, 2017).

It's easy to point the finger at dredging (see Pollock et al. 2014; Miller et al. 2016; Cunning et al. 2019) because it matches with our intuition that dredging can be bad and that it's something specific, a concrete thing that can be started and stopped, unlike global warming that causes coral bleaching that then makes corals more susceptible to disease (Hayes and Goreau 1998; Harvell et al. 2002; Bruno et al. 2007; Altizer et al. 2013; Burge et al. 2014; Manzello 2015; Maynard et al. 2015; Zvuloni et al. 2015; Merselis et al. 2018; Burge and Hershberger 2020). Thus, prevent global warming and you lessen coral stress (i.e. coral bleaching), and if you reduce coral stress then you get less disease (Rogers 2009; Randall et al. 2014; Hobbs et al. 2015; Randall and van Woesik 2017; Muller et al. 2018; Brodnicke et al 2019). This was especially relevant during the Port Miami project because this all happened at a time when state employees could not speak about 'climate change' or 'global warming' without significant personal and professional consequences (Korten 2015a, 2015b; Mooney 2015; 
The Guardian 2015). Also, when the story of corals dying near Miami appeared in the media it had a good hook, with a villain (Port Miami dredging and USACE) and a hero (the small NGOs standing up to Goliath). This false narrative about the Port Miami, however, is still being propagated (see Henderson et al. 2019). Unfortunately, this blame-game, while it has strong emotional appeal, retards scientific discovery and is right out of the playbook of climate change deniers (see Bradley 2011; Oreskes and Conway 2011; Mann and Toles 2016). Either way, it lessens our ability to improve on future projects by underestimating the real impacts due to global processes like increased sea surface temperatues (Manzello 2015), or regional impacts associated with poor wastewater and stormwater management (Marella 1998; Staley et al. 2017), while at the same time grossly overestimating those associated with local anthropogenic impacts such as dredging (Cunning et al. 2019). Thus, the epistemological distinction between science-based inference and the opinion that dredging caused mass coral mortality at the Port Miami clearly and overwhelmingly shows that the most of the coral mortality was not a result of the dredge project (Gintert et al. 2019; Precht et al. 2019; Spadafore et al. in-press). Not surprisingly, similar results have been previously reported on other dredging projects performed throughout South Florida over the past four decades (Griffin 1974; Marszalek 1982; Spring and Hodell 2011).

Unfortunately, by the time the regulators and resource managers finally concluded that the disease was for real, that it was devastating corals not just around the Port Miami area but on reefs throughout the region, and that they needed to pay closer attention, the disease had already spread a significant distance (over $100 \mathrm{~km}$ ) and was racing both north and south from its point of origin (see Precht et al. 2016). However, state regulators were still muzzled when it came to discussing the impacts of the regional thermal anomaly which was the root cause of the coral stress that was likely responsible for weakening the coral host and ultimately leading to the initiation of the disease (Precht et al. 2016; Gintert et al. 2019). It is also ironic that the first media coverage of the devastation wrought by this disease was not covered by the local press (the Miami Herald or the South Florida Sun Sentinel) but by the Washington Post on October 26, 2015 (Harvey 2015). It was not until April 24, 2016, 11/2 years after it was brought to the attention of state regulators that the disease finally made headlines in South Florida (Fleshler 2016). As a response to the growing number of disease reports throughout the region, in the spring of 2018 , some $31 / 2$ years after the disease was first observed, former U.S. Senator Bill Nelson (FL) who was then ranking member of the US Senate Committee on Commerce, Science, and Transportation asked for the help and expertise of multiple U.S. government agencies to identify the cause of the current disease outbreak and to mitigate the effects of the current 'environmental crisis' (Nelson 2018).

Based on the timeline and history of the response to this coral disease outbreak (see Table 1), what is even more ironic are recent articles that are discussing the 'race of Florida's agencies, NGOs, and scientists to find a cure to this coral killer.' These articles were written well more than three-years after onset of the disease (Fleshler 2017; Urry 2018). Racing - is three years really considered racing? My nightmare continues! However, for those managers and reef stewards dealing with this coral disease daily, it has not been a dream but a desperate reality. While much research and monitoring are presently being 
conducted, most of the questions regarding this catastrophic coral killer remain unanswered including the pathogen(s) responsible for this disease outbreak (Aeby et al. 2019; Meyer et al. 2019; Iwanowicz et al. 2020; Rosales et al. 2020; Ushijima et al. 2020).

Now, here we are some six years later and essentially the entire Florida Reef tract has been laid bare, with devastating levels of coral mortality ( $>30 \%)$ observed from Key West in the south and Martin County to the north (Figure 4). For perspective, this contrasts with COVID-19 mortality rates of about $1.8 \%$ in the United States (source, Johns Hopkins University December 9, 2020; https://coronavirus.jhu.edu/). Even more upsetting, the disease is now killing corals throughout the Caribbean (AlverezFilip 2018; The Daily Herald 2018; Alvarez-Filip et al. 2019; DPNR 2019; Lubofsky 2019; Martin 2019; Talbot 2019; Estrada-Saldivar et al. 2020; Dahlgren 2020), and again the same general suite of species are implicated with similar levels of coral mortality (Henderson et al. 2019). For instance, on reef sites monitored throughout the Yucatan of Mexico, Alvarez-Filip et al. (2019) noted "our percentage of afflicted colonies by the SCTLD is similar to what was observed in Florida during 2014-2015, where they registered a 30\% proportion of afflicted colonies.". As the disease has progressed through time and space, it went from being a local issue (Precht et al. 2016), to suddenly becoming a regional/national emergency (Nelson 2018), and now has become an international crisis (see AGRRA 2020; NOAA 2020; Precht 2020; Table 2).

The current outbreak of SCTLD is now considered by many to be worst coral disease ever recorded on a contemporary coral reef. Even scientists who initially dismissed the catastrophic impacts of SCTLD, like Andrew Baker have now been quoted as saying "It's probably the worst episode of coral disease on record, anywhere in the world, because of how widespread it is and because it affects multiple species..." (Brasileiro 2019a). So, which is it? An epizootic with only an $11 \%$ regional infection/mortality rate as purported in Cunning et al. (2019), or the worst coral disease on record? It can't be both.

\section{Management responsibility for SCTLD}

So, what could we have done differently, and would it have made any difference?

The first thing that you need to know about coral disease, or for that matter, any disease that occurs in the ocean, is that they can spread quickly and whatever causes the disease is often carried from one place to another by currents in the water (e.g. Lessios et al. 1984). On land, that's why diseases that spread through the air like COVID-19 are highly contagious. But on land, you can isolate the coughers and sneezers, or protect yourself (in some cases) with a vaccine or get treated by a therapeutic. Corals are not so lucky. There are no vaccines to protect them from disease or broad-scale antibiotics to treat them. And even if there were, how do you treat millions of corals that are located underwater over vast stretches of the seascape? Or, how do you stop the spread of disease when ocean currents are involved (McCallum et al. 2004)? It's a daunting challenge (Raymundo et al. 2020). A bad dream that has come to life with SCTLD, originally in Florida and now throughout the Caribbean (Precht 2020). 

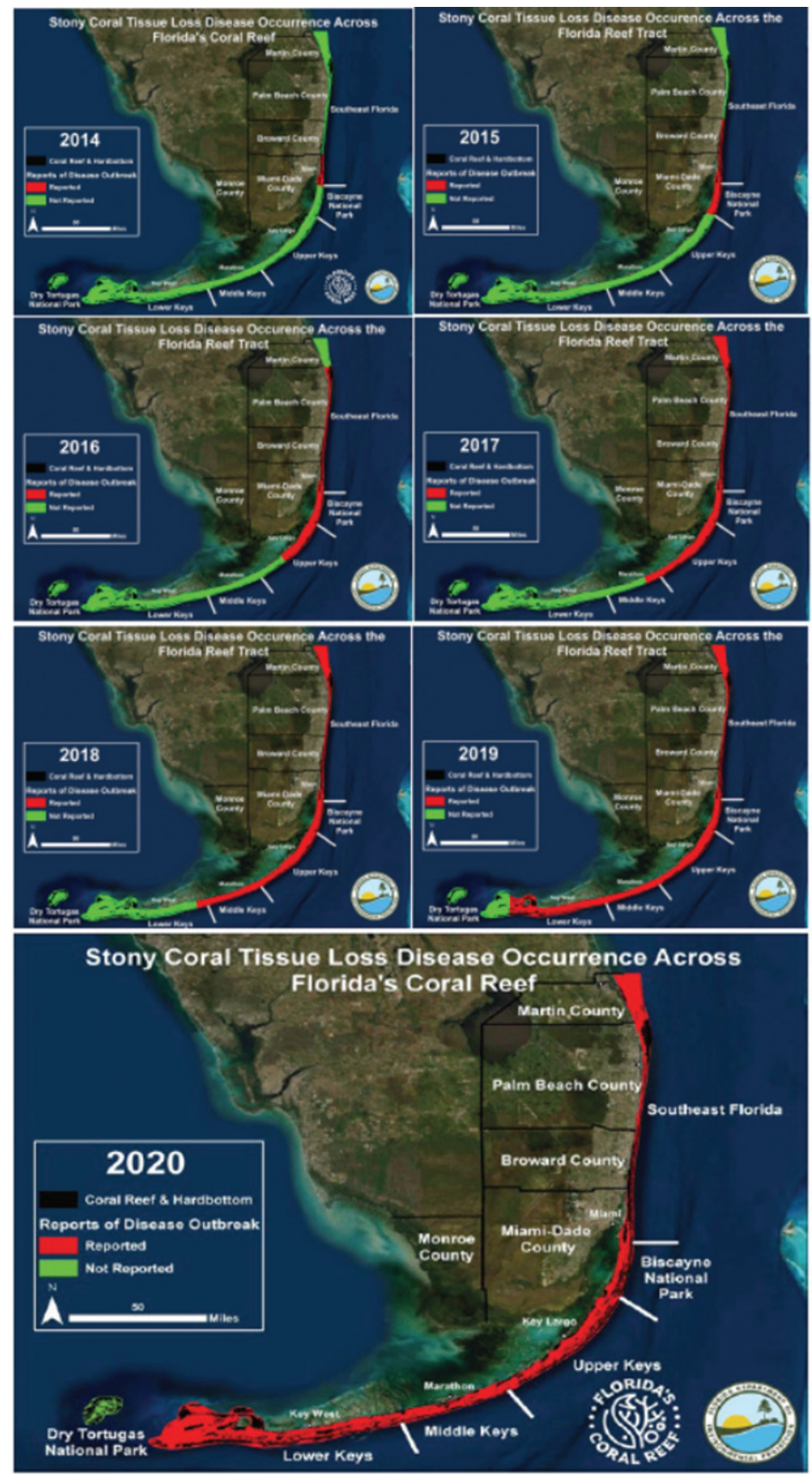

Figure 4. Going, going, almost gone! Map showing progressive spread and distribution of SCTLD across the Florida reef tract from 2014-2020 (shown in red). Note on the 2020 map only the Dry Tortugas have been spared the ravages of this outbreak. Spread was faster to the north than to the south and west due to the general flow direction of the prevailing Florida Current (Gulf Stream). Original SCTLD occurrence maps by year were prepared by FDEP and are available via open access through FDEP's SCTLD response website (https://floridadep.gov/rcp/coral/content/stony-coral-tissue-loss-disease-response). 
There is a noticeably short window of opportunity to intervene in disease eradication or control in the marine environment. During the early spread of this coral disease outbreak, some species losses, specifically those in the family Meandrinidae (Meandrina meandrites, Dichocoenia stokesi, and Eusmilia fastigiata, Dendrogyra cylindrus) may have been unavoidable due to the rapid spread and mortality of these highly susceptible species (Precht et al. 2016). But once infected, culling these species may have reduced spread to less susceptible species, especially during the initial onset of the outbreak. This is the one option that offers an opportunity to do something in the first moment when disease is discovered (Hayes and Goreau 1998). It's a similar response that is widely accepted as the only way to address the spread of invasive species - remove them before they have a chance to spread (Simberloff 2003). Examples of invasive species in Florida that spread quickly and unchecked that today have become a nuisance include Melaleuca, Australian Pine and Brazilian Pepper trees as well as animals such as pythons, iguanas and lionfish to name just a few. There are now control plans and protocols for each of these species including bounties and incentives on some (Kline and Duquesnel 1996; Serbesoff-King 2003; Macaluso 2016; Weekman 2017).

The manipulative action of removing infected coral colonies is clearly a drastic management response with numerous challenges that include ethical considerations and regulatory permit complications, yet the rapid and near total collapse of local coral populations during this multi-year outbreak requires that drastic actions are needed to slow the spread of this and future diseases that threaten what remains of our already endangered coral reefs. Similar management policies have been implemented where large swaths of vegetation are commonly eradicated in terrestrial systems with varying degrees of success (Gottwald et al. 2001; Sosnowski et al. 2009; Centner and Ferreira 2012). This is a common practice, especially when valuable cash crops such as citrus groves are at risk from disease (Hall and Gottwald 2011). Experimental work will help identify how many corals need to be removed and how fast. Monitoring work to evaluate the effectiveness of this dramatic recommendation will be also be needed to document its effectiveness (Smith and Cheeseman 2002). This is not to suggest that we need to know more about disease progress before acting. Instead, this is an example of the need to act fast in an emergency, because to not act ultimately dooms you to failure (Balzoni et al. 2014). Unfortunately, examples of such failure abound in the Florida response to SCTLD.

As a result of this disease in South Florida, the iconic pillar coral Dendrogyra cylindrus, a U.S. Endangered Species Act listed species, has been ecologically extirpated from our regional seascape (Neely and Lewis 2020). We essentially monitored the impacts of the disease on the infected colonies (Kabay et al. 2017; Lewis et al. 2017) instead of actively intervening to save them until it was too late (Lewis 2016; O'Neil et al. 2018; Neely and Lewis 2020). The figure below shows what happens when you do nothing (Figure 5). In contrast, when pillar corals were recently impacted in Grand Cayman by a white-plague-like disease outbreak, the Cayman Islands Department of the Environment responded rapidly with a multi-pronged approach that resulted in high survivorship of the affected colonies (Warrender et al. in press). While time-intensive, the lessons 


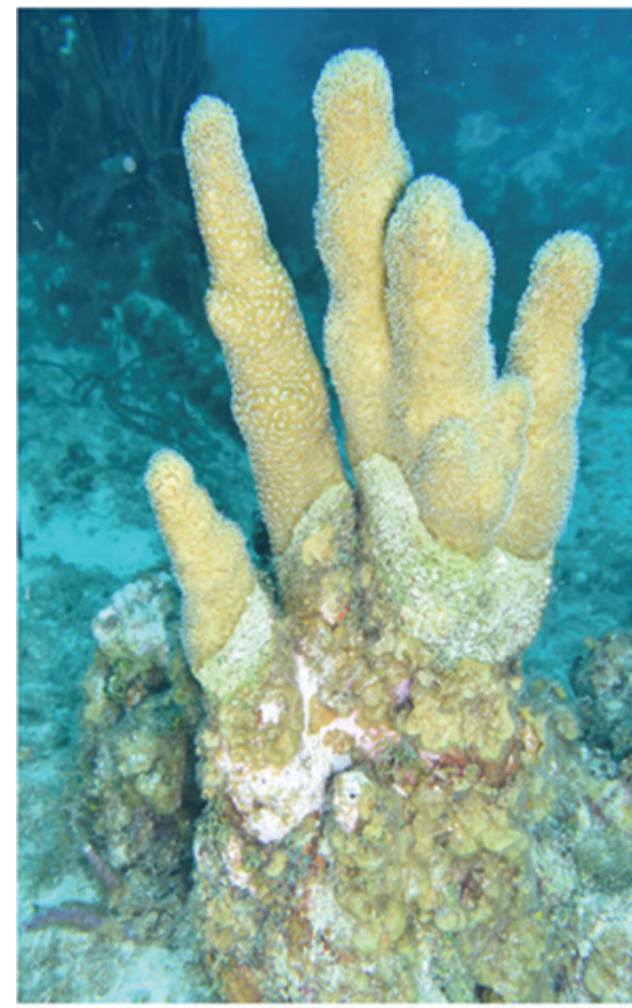

August 2018

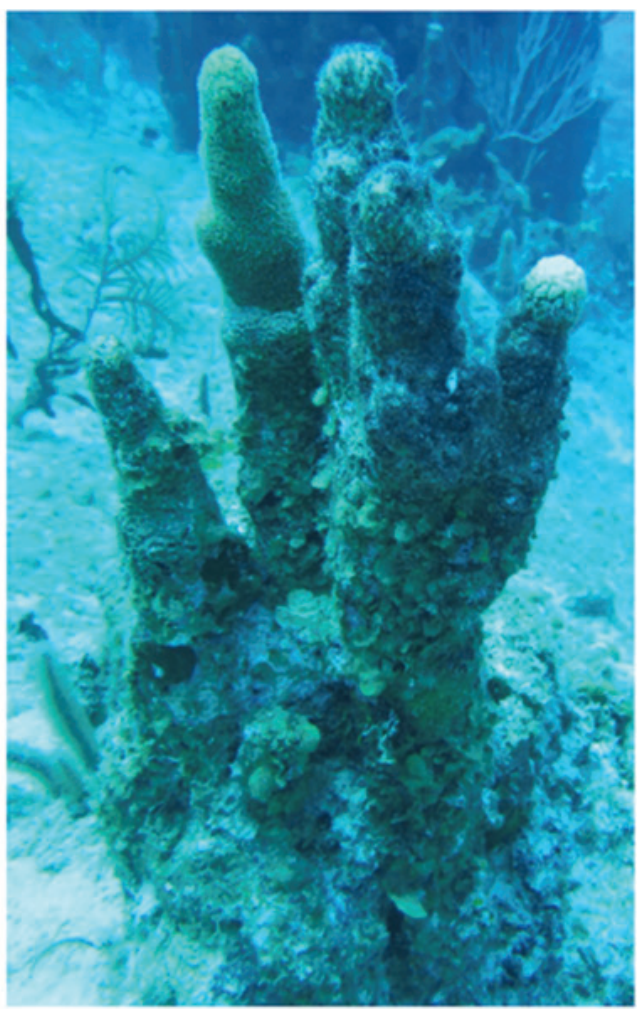

September 2019

Figure 5. The depressing reality of failing to respond. An example of monitoring corals to death instead of actively intervening to save them. Progressive loss of Dendrogyra cylindrus colony associated with SCTLD. More than $90 \%$ of the colony was lost in about one-year.

learned from the Cayman experience shows that early intervention can have a positive impact. Not every coral can be saved, but the largest and most iconic and charismatic species are clearly potential targets for intervention (see Walker and Brunelle 2018).

At present, there are few other options available to stop or ameliorate a disease once an outbreak has occurred (Teplitski and Ritchie 2009). For instance, while the use of biocides, disinfectants, antimicrobial agents, and chemical treatments are commonly used to treat diseases in aquaculture and the aquarium trade, these are not viable methods for use in the open ocean due to their undesirable environmental toxicological consequences (Rodgers and Furones 2009; Sweet et al. 2012; Sheridan et al. 2013). In a few cases, coral diseases caused by bacterial infections have been successfully treated using antibiotics in laboratory settings (Kline and Vollmer 2011; Sweet et al. 2014) while in others there appears to be multi-drug resistance to commercial antibiotics (Vizcaino et al. 2010). However, in-water treatment with antibiotics is generally not considered a viable option because of the general effect of antibiotics on all bacteria including probiotics responsible for regulation of the coral microbiome as well as ecosystem health 
(Reshef et al. 2006; Ritchie 2006). In addition, there are potential dangers of selection for antibiotic-resistant strains of diseases that could ultimately make matters worse (Parisien et al. 2007). In a last-ditch effort to save some of the larger diseased colonies in Florida, researchers have been field-testing the use of an antibiotic putty that is placed around diseased lesions to create a 'pharmaceutical barrier' to prevent its spread (Walker and Brunelle 2018). To date, the results of these field trials show that while they are extremely time-intensive to perform the results have generally been positive (Neely and Lewis 2018; Neely et al. 2020; Urry 2019; Neely 2020). More recently, probiotic treatments of SCTLD infected corals in the laboratory have also yielded some promising results (Donahue 2019) and are currently being field tested.

One emerging remedial method for coral disease that shows some potential is phage therapy (Parisien et al. 2007; Doss et al. 2017). Lytic bacteriophages (phages) can be isolated from bacterial pathogens that are known to be directly responsible for coral diseases. By using these phages in experimental settings, it has been demonstrated that coral diseases can be controlled by the pathogen-specific phage (Efrony et al. 2009; Atad et al. 2012; Cohen et al. 2013). The initial data from these studies, indicate that the phages bind to the pathogen in seawater and are then brought to the coral surface where they multiply and lyse the pathogen. These phages multiply as long as their bacterial hosts are present and thus could also prevent subsequent infections. These studies suggest that phage therapy has the potential to control the spread of infectious bacterial coral diseases (Soffer et al. 2015). Unfortunately, in the case of the recent coral disease outbreak in southeastern Florida there has been no specific pathogen identified to-date that has be isolated (Paul et al. 2018; Aeby et al. 2019; Meyer et al. 2019; Iwanowicz et al. 2020; Rosales et al. 2020; Ushijima et al. 2020) and could be used in phage therapy treatments. Our lack of knowledge on the eitiology of this disease continues to remain a mystery; this is an important point that cannot be emphasized enough.

There is another failure to talk about, which is the fact that more than 40 years after the first coral disease epidemic (white-band disease) killed billions of corals throughout the Caribbean and Florida (Gladfelter 1982; Precht and Aronson 1997; Aronson and Precht 2001; Gignoux-Wohlfsohn et al. 2019), little advancement occurred in the identification (Pollock et al. 2011) and our knowledge of coral disease epidemiology (Peters 1984, 2015; Harvell et al. 2004; Ainsworth et al. 2007; Mera and Bourne 2018; Vega Thurber et al. 2020). Indeed, there remain only a handful of marine biologists with formal training in the study and treatment of coral diseases. Why is that the case? Why haven't marine biologists been successful about bringing resources to bear on this as compared to their terrestrial counterparts (i.e. Brand 2013)? Is it a failure to communicate or something larger about our society that is resistant to caring about ecosystem losses that are in the marine realm? Is out of sight, out of mind?

Beeden et al. (2012) stated many of these various remedial response actions proposed for coral disease abatement are highly experimental and likely to be prohibitively expensive on all but the smallest of spatial scales. However, are those justifiable reasons for not responding? Knowing what we know now about the catastrophic nature of the 2014-present coral disease outbreak, it would be disingenuous to argue that interven- 
ing is not a viable management option. No matter how large the expense, these costs will dwarf the potential financial losses associated with disease-related coral ecosystem collapse presently being observed throughout Florida and the the Caribbean. For instance, Florida's coral reef ecosystem supports $>70,000$ jobs equaling to about $\$ 8.5$ billion in sales and income annually. Thus, the loss of eco-tourism and commercial and recreational fisheries alone that can be tied directly to this disease could potentially be in the billions of US dollars (NOAA 2020).

In a few short years, the ecological extirpation of many key charismatic species has fundamentally changed the way reefs throughout south Florida look and function, resulting in a depauperate community of small, ephemeral, weedy, stress-tolerant species (Burman et al. 2012; Precht et al. 2016, 2018; Toth et al. 2019). In addition, the conservation of species-specific disease susceptibility traits, region-wide, suggests that local management efforts aimed at improving reef resilience to-date have been ineffective at preventing and minimizing the impacts of coral disease outbreaks. For instance, a recent effort to map reef areas of high and low resilience to climate change in south Florida (Maynard et al. 2017) showed no difference in coral mortality patterns from the current disease outbreak no matter the mapped resilience score. Plain and simple, if you were a highly susceptible species to SCTLD you got whacked and if you weren't, then you didn't (Gintert et al. 2019).

\section{The long view on controlling coral disease outbreaks}

The response of coral reef organisms to global climate change in all of its manifestations (bleaching, disease, and acidification) can occur through both genetic and nongenetic processes (adaptation versus acclimization). Therefore, the potential exists for using genetic manipulation to build coral reef resilience through assisted evolution (NAS 2018). Presently, there is no evidence for wide-spread adaptation or acclimatization of reef corals to the effects of climate change (van Oppen et al. 2015). However, the possibility exists that epigenetic modifications of corals may be used to develop advantageous phenotypic effects through controlled stress exposure. For instance, Vollmer and Kline (2008) noted that six percent of staghorn coral (Acropora cervicornis) genotypes were resistant to white-band disease (WBD) in Bocas del Toro, Panama. This natural resistance to WBD in staghorn corals demonstrated that staghorn corals have an innate ability to resist WBD infection and may explain why areally limited thickets of Acropora have been able to survive the WBD epidemic (see Greer et al. 2020) that has been ravaging acroporid coral populations throughout Florida and the Caribbean since the mid-1970's (Gladfelter 1982; Precht and Aronson 1997; Aronson and Precht 2001). Thus, understanding the genetic basis for disease resistance in corals may be a critical link to restoring populations of reef building corals in the future (van Oppen and Gates 2006; Baums 2008; Miller et al. 2019). Similar on-going research is being performed in Florida with citrus crops (Ledford 2017). While this research is currently fraught with theoretical and ethical questions regarding the creation of anthropogeni- 
cally enhanced systems (van Oppen et al. 2015), if successful, the future introduction of genetically selected corals that are immune to various coral diseases may enable reefs to persist and possibly recover in an ever changing world.

\section{Can we apply any lessons learned from the COVID- 19 response?}

What Barack Obama learned during his tenure as President was that any American response to a human pandemic had to be an all-in government response, where all agencies involved needed to coordinate closely with each other including the National Institutes of Health (NIH) and the CDC. Thus, a pandemic assessment strategy (playbook) was established that specifically outlined how the U.S. government should respond to a pandemic (NSC 2016). However, when COVID-19 first appeared in the U.S., the Trump administration failed to follow this playbook with grave consequences (Diamond and Toosi 2020).

Whatever actions are taken, like with COVID-19, they must be implemented swiftly before the pathogen has a chance to spread and cover large areas (Morgan and Wang 2020). With human pandemics response times need to be implemented in hours to days, not weeks or months. Where would we be had the response to SCTLD started immediately? While we will never know the answer, one thing is for sure, for SCTLD we would be at a minimum two years ahead of where we are now regarding our present level of knowledge and research on this devastating coral killer. Those two years lost can never be recovered. However, with SCTLD, this is further complicated because the pathogen continues to remain a mystery, diminishing the effectiveness of many in-water treatment options. In the case of the SCTLD event in southeast Florida, the slow management response to this outbreak (Table 1) left no real viable options available for eradication or control. As a result, we are now sadly faced with a situation where our management efforts are focused almost exclusively on the rescue of genetic material from coral species at risk of regional extinction instead of disease abatement measures (Lewis 2016; Kimel 2018; O’Neil et al. 2018; Klingener 2019; Newborn, 2019; Brasileiro 2019a, 2019b). Hopefully, these resuced corals may serve as the seed source for future restoration efforts. This, however, remains a challenge for the future.

It is vitaly important that the level of coordination and speed of response to potential disease outbreaks must be increased if we have any chance of preserving what remains of our coral populations. Therefore, a rapid, multi-pronged approach is required and at a minimum should contain the following core components:

- Establish an island, state, or country specific coral disease taskforce comprised a diverse group of stakeholders including but not limited to local government officials, regulatory scientists, local NGO's, acadamicians, aquariums, scientists from the private sector, citizen scientists, and local dive operators. This taskforce should be assembled in advance of and not as an ad hoc response to a disease outbreak. 
- Build a collaborative operational framework to effectively integrate and manage the taskforce.

- Develop an island, state, or country specific coral disease emergency response plan written by the taskforce.

- The taskforce should be comprised of a 'strike team' whose members are actively engaged in surveillance, monitoring, sampling, laboratory analysis, emergency response, information dissemination, communication, and community outreach.

- Have a team of QA/QC experts that functions independently of the taskforce. This independence assures unbiased oversight and reviews for the benefit of the overall goals of the taskforce and accordingly, the resource.

- On first observation of a coral disease outbreak, enact emergency response plan where the science and the disease drive response decisions.

- Collect samples for eitiological analysis to potentially isolate the pathogen(s) associated with the disease.

- Design and implement hypothesis-driven, monitoring efforts with internal feedback loops that allow science-based observations to drive adaptive management decisions.

- Share information/correspondence within and between all taskforce members in real-time through web-based platforms (i.e. MPAConnect Dash Board/AGRRA 2020).

- Identify and map locations of observed coral disease outbreak(s).

- Report which species are susceptible and those that are not at disease locations.

- Track the rate of spread of the disease across individual corals.

- Perform epidemiological monitoring of the disease spread within and across reefs in both time and space. Determine whether disease is progressing in a predictable, step-wise manner or jumping around from coral to coral and reef to reef.

- Perform continuous repeated measures monitoring of specific sites through time to document changes in coral reef community structure.

- Note if there are potential biological agents (vectors) that may be responsible for local disease spread such as fish and mobile invertebrates.

- Implement location specific, coral disease outbreak rapid response plan including intervention methods (i.e. physical removal of colonies by either culling of diseased corals or removal of iconic species or individual colonies), and/or implementation of various ameilioration strategies (i.e. use of antibiotics, probiotics, etc.) as outlind in the response plan.

- Establish, both field and laboratory-based experiments related to potential intervention/amelioration methods.

- Carefully document results of intervention/amelioration methods. Key in on those methods that appear to produce best results so these methods can be scaled-up rapidly.

- Educate the local maritime industry members, boaters, the dive community, and visitors on the disease and ways to potentially stop its spread using 'precautionary' best management practices which may include the temporary closure of popular dive or fishing sites.

- Perform rapid and continuous coordination and communication with experts and other groups involved in responding to similar coral disease outbreaks in other 
areas, especially AGRRA (presently responsible for tracking SCTLD spread throughout the Caribbean).

- Develop coral nurseries or hospitals including the rescue of genetic materials for future (post epidemic) outplanting and restoration programs.

- Responsibly disseminate scientific results as quickly as possible through press releases, blog posts, government/agency/NGO/academic white papers, and peer-reviewed publications so 'lessons learned' can be shared with other scientists/managers at other locations.

Most importantly, all these efforts require funding so government agencies with purview over these valuable resources need to make significant financial investments if there is any chance of saving what is left. These costs should be viewed as both an environmental and economic mandate. As noted above, these investments will dwarf the potential financial losses associated with disease-related coral ecosystem collapse presently being observed throughout Florida and the the Caribbean associated with this SCTLD outbreak. Crtically, there is a need for all stakeholders to petition government agencies for 'State of Emergency' designations when marine species, especially those that are under immediate threat of rapid local extinction, are at risk from acute disturbances. These designations could help bring visibility and additional funds to these regional-scale disturbances that will help support more comprehensive response efforts in the future.

For the initial COVID-19 response in the United States, or lack thereof, the failure is unfortunately measured in human lives lost. What would disease infection and mortality rates be had a coordinated effort been undertaken at the onset of this outbreak? For a stark example, below is a graphic comparing coronavirus death rates between the United States and South Korea (Figure 6). The United States and South Korea each had their first confirmed case of the coronavirus on January 20, 2020. Both countries suffered their first death in late February 2020. However, the graphs strongly diverged in March 2020. The main reason that South Korea's mortality rate remained low and flat while the U.S. numbers have soared has everything to do with the early response (Oh et al. 2020; Solano et al. 2020). From the initial case, South Korea took the virus extremely seriously having heard the horror stories coming out of Wuhan, China (McNeil 2020). South Korea was prepared and implemented a rapid, coordinated effort with widespread testing, the tracking of cases, and quarantining those exposed to the virus from the onset (Berger 2020; Leonhardt 2020; Morgan and Wang 2020). This compares with at least a six-week period from late January into March 2020 where the United States essentially did nothing while President Trump determined that such measures were unnecessary and the virus would "miraculously disappear on its own in the spring" (O'Conner 2020). It obviously did not. Thus, the failure to respond in a timely fashion, the lack of a coordinated interagency effort, the gross underestimation and denial of the virulence of the COVID-19 pandemic, the intentional disregard of the scientific facts (Zenko 2020), and the subsequent blame-game (Quinn 2020), has left the U.S. in the notorious position of having the most confirmed cases and deaths 


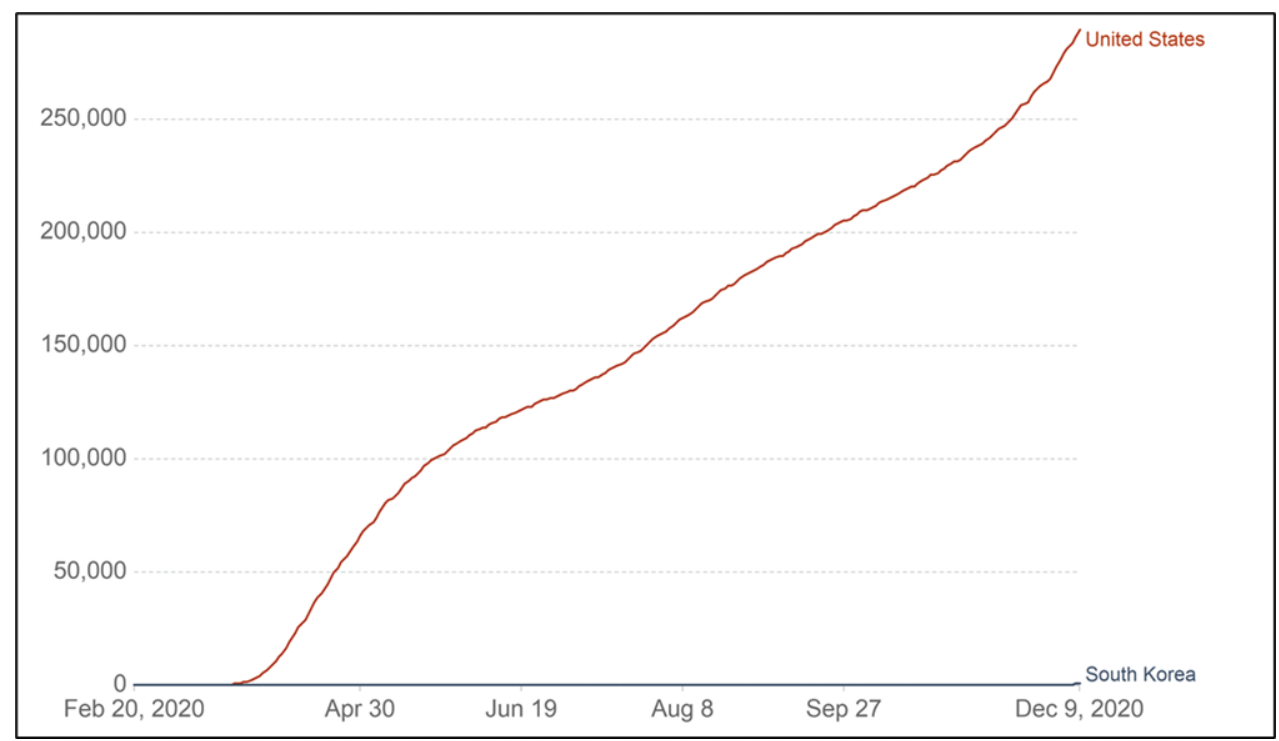

Figure 6. Graph of human deaths associated with COVID-19 in 2020. Comparison between mortality in the United States (red graph) and South Korea (blue graph). As of December 9, 2020 the difference in mortality between these two countries continues to diverge with the United States reporting a total of 292,611 COVID-19 related deaths while South Korea only 572 (data source, Johns Hopkins University 2020; https://coronavirus.jhu.edu/). So, while the U.S. population is 6.3 times greater than that of South Korea, its COVID-19 mortality is 511.6 times greater.

from COVID-19 (as of December 9, 2020, the United States has approximately 4.4\% of the world's population, but has $22.3 \%$ of the reported cases and $18.4 \%$ of the known deaths associated with the COVID-19 pandemic; source Johns Hopkins University 2020; https://coronavirus.jhu.edu/).

So what are the similarities between the failures observed in the response to COVID-19 and SCTLD? The two most obvious include the failure to let scientific data and the facts drive the decision-making process and even worse, the obfuscation of the truth that fomented conspiracy theories and claims of cover-ups based on personal ideologies or political agendas (Pence 2020; Shepard 2020; Quinn 2020). Misinformation, fake news, or news with fabricated content and sensational headlines have emerged as major stumbling blocks to communicating with the general public including policy makers on how to respond to real public health and environmental threats (see Boykoff 2009; Thaler and Shiffman 2015; Scheufele and Krause 2019). However, one thing is certain, neither COVID-19 or SCTLD are hoaxes, or fake, and they will not miraculously disappear overnight. Importantly, their effects have not been overblown or exaggerated but are likely under-representations of the published data (Giattino 2020; Woolf et al. 2020). Specifically, the State of Florida has failed miserably at responding to both disease outbreaks with horrific consequences (Prasad 2020; Sinclair 2020), and many of these failures continue. If there is a main message 
that emerges from these two concurrent diseases is it is incumbent on us as scientists to fully understand our failures, why they occurred, and what the lessons-learned portend for the future. Only then, will we be able to respond more quickly and effectively to disease outbreaks.

\section{The future for Caribbean reefs}

While ocean temperatures have increased over the last few decades in the tropics and subtropics, the resulting ecosystem decline that ensued has been devastating. If SCTLD continues to spread and linger throughout the region the outlook for the Caribbean reef-scape is bleak. Thus, the combination of bleaching stress and numerous coral diseases, including the recent emergence of SCTLD portends doom to a reef ecosystem already at a tipping point from multiple stressors, both natural and anthropogenic. An important question to ask is will these unprecedented losses including the extirpation of some charismatic coral species like the iconic pillar coral, Dendrogyra cylindrus serve as a wakeup call to act so we can protect, preserve and ultimately restore what is left of these fragile marine ecosystems in the face of global warming and other local and regional stressors (Neely and Lewis 2020). The links between increased ocean temperature, bleaching, and deadly marine epizootics should not be ignored, and climate-mediated ecosystem decline should be considered a contemporary and existential threat instead of a future one. The same can be said for human pandemics (Goodell 2020). Accordingly, immediate global action to curb future warming through reduction of greenhouse gas emissions is essential if we are to secure a future for coral reefs and the health of our planet (Aronson and Precht 2006, 2009, 2016; Gintert et al. 2019).

Ironically, six years to the week of Precht's original email, NOAA (2020) has published a national SCTLD strategy. The strategy is intended to provide a framework that focuses on efforts to slow the continued spread of the disease across the region, and to prevent and prepare for the potential spread of the disease into the Indo-Pacific. One of the main goals of this strategy is to inform a national-level implementation plan to be developed in 2021 (Table 1). While these documents are welcome, they are long overdue. Based on the current status of the COVID-19 pandemic, I doubt we would find it acceptable for the NIH or the CDC to finally prepare a COVID-19 strategy in 2025 with a follow-up implementation plan to be rolled out in 2026. So why should we expect less from our agencies responsible for stewardship of our valuable coral resources?

As previously discussed, we have no time to waste. SCTLD continues to ravage coral communities throughout Florida and the Caribbean and we can no longer stand idley by and do nothing. If there is one take away from the lessons learned from SCTLD in South Florida, time is not on our side. Thus, experimental removal, culling, salvage, intervention, and ameilioration efforts based on the best available science must be attempted to save corals impacted by SCTLD as the risk of doing nothing is no longer a viable option (see The Vigin Islands Daily News 2020). Certainly, if this on-going coral disease continues to spread throughout the Caribbean at its current pace, the whiteband disease outbreak that devastated the Caribbean Acropora species (Aronson and 
Precht 2001) will ultimately pale in comparison. Then we may, in-fact, be looking at the regional ecological extinction of numerous key reef-building species that may result in the total collapse of what remains of our coral reefs. Indeed, the spectacularly beautiful and biologically rich coral reefs that some of us experienced early in our careers, and our parents enjoyed without fear of their loss, will resemble flat concrete parking lots that our children and grandchildren will inherit. That's my nightmare come to life.

\section{Acknowledgements}

Funding for the Port Miami data collection was supported to DCA in-part under contracts to Great Lakes Dredge and Dock Company, LLC (GLDD) sponsored by the USACE, Jacksonville District and Port Miami, Miami-Dade County from 20132017 for environmental compliance monitoring and analysis under FDEP Permit No. 0305721-001-BI. The funders had no role in data collection and analysis, decision to publish, or preparation of the manuscript.

This perspective benefitted greatly from conversations over the past few years with Lorenzo Alvarez-Filip, Rich Aronson, Craig Dahlgren, Ryan Fura, Sarah GignouxWolfsohn, Brooke Gintert, Les Kaufman, Judy Lang, Alex Modys, Martha Robbart, Lauren Toth, Rob van Woesik, Steve Vollmer, and especially Les Kaufman. Thanks to Ian Enochs (NOAA-AOML) and Bill Sharp (FWC) for providing unpublished data from their regional monitoring programs used in Table 3. Special thanks to Steven Miller for guidance, council, encouragement, and insightful editing. However, the views, statements, findings, conclusions and recommendations expressed herein are exclusively my own. This manuscript is dedicated to my late father Frederick C. Precht for always being my 'North Star.' I specifically wrote this for my wife and three daughters who continually inspire me to never stop fighting, especially when the cause is just.

\section{References}

Aeby G, Ruzicka R, Bohnsack K (2017) Status and trends from a large-scale coral disease outbreak. $38^{\text {th }}$ Meeting of the US Coral Reef Task Force. Fort Lauderdale, FL. https://coralreef. gov/meeting38/docs/status_lessons_learned_coral_disease_outbreak.pdf [August 11, 2017] Aeby G, Ushijima B, Campbell JE, Jones S, Williams G, Meyer JL, Hase C, Paul V (2019) Pathogenesis of a tissue loss disease affecting multiple species of corals along the Florida Reef Tract. Frontiers in Marine Science 6: 678. https://doi.org/10.3389/fmars.2019.00678 AGRRA (Atlantic and Gulf Rapid Reef Assessment) (2013) Coral Codes - Revision: 2013-0401. https://www.agrra.org/training-tools/agrra-datasheets/

AGRRA (Atlantic and Gulf Rapid Reef Assessment) (2020) Coral disease outbreak, stony coral tissue loss disease. http://www.agrra.org/coral-disease-outbreak/

Ainsworth TD, Kramasky-Winter E, Loya Y, Hoegh-Guldberg O, Fine M (2007) Coral disease diagnostics: what's between a plague and a band? Applied and Environmental Microbiology 73(3): 981-992. https://doi.org/10.1128/AEM.02172-06 
Altizer S, Ostfeld RS, Johnson PT, Kutz S, Harvell CD (2013) Climate change and infectious diseases: from evidence to a predictive framework. Science 341(6145): 514-519. https:// doi.org/10.1126/science.1239401

Alverez L (2011) Fears in Miami that port expansion will destroy reefs. The New York Times. http:// www.nytimes.com/2011/09/04/us/04coral.html?pagewanted=all\&_r=0 [September 3, 2011]

Alverez L (2016) Dredging of Miami port badly damaged coral reef, study finds. The New York Times. https:/www.nytimes.com/2016/05/02/us/dredging-of-miami-port-badlydamaged-coral-reef-study- finds.html [May 1, 2016]

Alvarez-Filip L (2018) Outbreaks of Caribbean coral disease on the rise. BARCO LAB: https:// www.barcolab.org/copy-of-outbreak-of-caribbean-coral

Alvarez-Filip L, Estrada-Saldívar N, Pérez-Cervantes E, Molina-Hernández A, González-Barrios FJ (2019) A rapid spread of the stony coral tissue loss disease outbreak in the Mexican Caribbean. PeerJ 7: e8069. https://doi.org/10.7717/peerj.8069

Aronson RB, Precht WF (2001) White-band disease and the changing face of Caribbean coral reefs. Hydrobiologia 460: 25-38. https://doi.org/10.1007/978-94-017-3284-0_2

Aronson RB, Precht WF (2006) Conservation, precaution, and Caribbean reefs. Coral reefs. 2006 25(3): 441-50. https://doi.org/10.1007/s00338-006-0122-9

Aronson R B, Precht WF (2009). Sustaining ecosystem services in the global coral reef crisis. American Institute of Physics Conference Proceedings 1157(1): 48-55. https://doi.org/10.1063/1.3208031

Aronson RB, Precht WF (2016) Physical and biological drivers of coral-reef dynamics. In Hubbard DK, Rogers CS, Lipps JH, Stanley Jr GD (Eds) Coral Reefs at the Crossroads. Dordrecht: Springer, 261-265. https://doi.org/10.1007/978-94-017-7567-0_11

Atad I, Zvuloni A, Loya Y, Rosenberg E (2012) Phage therapy of the white plague-like disease of Favia favus in the Red Sea. Coral Reefs 31(3): 665-670. https://doi.org/10.1007/ s00338-012-0900-5

Baker AC (2015) Coral Reef Conservation Lab (CR2) Coral Disease Outbreak at Emerald Reef, Facebook Posting. https://m.facebook.com/pages/Baker-Coral-Reef-ConservationResearch-Laboratory/147275378670311 [April 30, 2015]

Bardon A (2019) The Truth about Denial: Bias and Self-deception in Science, Politics, and Religion. Oxford University Press. https://doi.org/10.1093/oso/9780190062262.001.0001

Baums IB (2008) A restoration genetics guide for coral reef conservation. Molecular Ecology 17: 2796-811. https://doi.org/10.1111/j.1365-294X.2008.03787.x

Bolzoni L, Tessoni V, Groppi M, De Leo GA (2014) React or wait: which optimal culling strategy to control infectious diseases in wildlife. Journal of Mathematical Biology 69(4): 1001-1025. https://doi.org/10.1007/s00285-013-0726-y

Beeden R, Maynard JA, Marshall PA, Heron SF, Willis BL (2012) A framework for responding to coral disease outbreaks that facilitates adaptive management. Environmental Management 49(1): 1-13. https://doi.org/10.1007/s00267-011-9770-9

Bojko J, Lipp E, Ford A, Behringer D (2020) Pollution can drive marine diseases. In: Behringer DC, Silliman BR, Lafferty KD (Eds) Marine Disease Ecology. Oxford University Press, 95-113. https://doi.org/10.1093/oso/9780198821632.003.0006

Boykoff MT (2009) We speak for the trees: media reporting on the environment. Annual Review of Environment and Resources 34: 431-457. https://doi.org/10.1146/annurev. environ.051308.084254 
Bradley RS (2011) Global Warming and Political Intimidation: How Politicians Cracked Down on Scientists as the Earth Heated Up. University of Massachusetts Press.

Brand CJ (2013) Wildlife mortality investigation and disease research: contributions of the USGS National Wildlife Health Center to endangered species management and recovery. Ecohealth 10(4): 446-54. https://doi.org/10.1007/s10393-013-0897-4

Brasileiro A (2019a) Scientists collect healthy corals for gene bank as mysterious disease decimates reefs. Miami Herald. https:/www.miamiherald.com/news/local/environment/article232326102.html [July 5, 2019]

Brasileiro A (2019b) A 'Noah's Ark' project for corals: scientists race to save Florida reef from killer disease. Miami Herald. https://www.miamiherald.com/news/local/article230811249. html [May 30, 2019]

Brodnicke OB, Bourne DG, Heron SF, Pears RJ, Stella JS, Smith HA, Willis BL (2019) Unravelling the links between heat stress, bleaching and disease: fate of tabular corals following a combined disease and bleaching event. Coral Reefs 38: 591-603. https://doi.org/10.1007/ s00338-019-01813-9

Bruno JF, Selig ER, Casey KS, Page CA, Willis BL, Harvell CD, Sweatman H, Melendy A (2007) Thermal stress and coral cover as drivers of coral disease outbreaks. PLoS Biology 5(6): e124. https://doi.org/10.1371/journal.pbio.0050124

Burge CA, Eakin MC, Friedman CS, Froelich B, Hershberger PK, Hofmann EE, Petes LE, Prager KC, Weil E, Willis BL, Ford SE (2014) Climate change influences on marine infectious diseases: implications for management and society. Annual Review of Marine Science 6: 249-277. https://doi.org/10.1146/annurev-marine-010213-135029

Burge CA, Hershberger PK (2020) Climate change can drive marine diseases. In: Behringer DC, Silliman BR, Lafferty KD (Eds) Marine Disease Ecology. Oxford University Press, 83-94. https://doi.org/10.1093/oso/9780198821632.003.0005

Burman SG, Aronson RB, van Woesik R (2012) Biotic homogenization of coral assemblages along the Florida reef tract. Marine Ecology Progress Series 467: 89-96. https://doi. org/10.3354/meps09950

Butler R (2009) Blackwashing by NGOs, greenwashing by corporations, threatens environmental progress. Mongabay. https:/news.mongabay.com/2009/11/blackwashingby-ngos-greenwashing-by-corporations-threatens-environmental-progress/ [November 12, 2009]

Centner TJ, Ferreira S (2012) Ability of governments to take actions to confront incursions of diseases-a case study: citrus canker in Florida. Plant Pathology 61(5): 821-828. https:// doi.org/10.1111/j.1365-3059.2011.02575.x

CNR (Committee on Natural Resources) (2012) Taxpayer-funded litigation: benefitting lawyers and harming species, jobs and schools. Oversight Hearing Before The Committee On Natural Resources, U.S. House Of Representatives $112^{\text {th }}$ Congress. https://www.govinfo.gov/content/pkg/CHRG-112hhrg74665/html/CHRG-112hhrg74665.htm [June 19, 2012]

Cohen Y, Pollock JF, Rosenberg E, Bourne DG (2013) Phage therapy treatment of the coral pathogen Vibrio coralliilyticus. Microbiology Open 2(1): 64-74. https://doi.org/10.1002/mbo3.52

Corry S (2018) What's the real story behind the Botswana elephant deaths false claims? African Arguments. https://africanarguments.org/2018/10/02/whats-real-story-behind-botswanaelephants-deaths-fake-news/ [October 2, 2018] 
Cróquer A, Weil E, Zubillaga AL, Pauls SM (2005) Impact of a white plague-II outbreak on a coral reef in the archipelago Los Roques National Park, Venezuela. Caribbean Journal of Science 41(4): 815-823.

CSI (Coastal Systems International, Inc.) (2016) Transplanted corals to artificial reefs - 24 month post transplant monitoring report. Prepared for Miami Harbor Phase III Federal Channel Expansion. PortMiami, Miami-Dade County Contract No. E12-SEA-03/Project No. 1999-027.

Cunning R, Silverstein RN, Barnes BB, Baker AC (2019) Extensive coral mortality and critical habitat loss following dredging and their association with remotely-sensed sediment plumes. Marine Pollution Bulletin 145: 185-199. https://doi.org/10.1016/j.marpolbul.2019.05.027

Dahlgren C (2020) Stony coral tissue loss disease (SCTLD): a new threat to Bahamian Reefs. Perry Institute of Marine Science. https://www.youtube.com/watch?v=GWaTceffwYk\&fe ature=youtu.be [webinar April 15, 2020]

DCA (Dial Cordy and Associates, Inc.) (2015a) Quantitative post-construction analysis for hardbottom benthic communities. FDEP Final Order \#0305721-001-BI. 2012, PortMiami Phase III Federal Channel Expansion Project. Florida Department of Environmental Protection, Tallahassee, FL. http://www.saj.usace.army.mil/Portals/44/docs/Navigation/ Ports/Miami\%20Harbor/Near-ShoreHard-BottomReportNov2015.pdf

DCA (Dial Cordy and Associates, Inc.) (2015b) Quantitative post-construction analysis for middle and outer reef benthic communities. FDEP Final Order \#0305721-001-BI. 2012, PortMiami Phase III Federal Channel Expansion Project. Florida Department of Environmental Protection, Tallahassee, FL. http://www.saj.usace.army.mil/Portals/44/docs/Navigation/Ports/Miami\%20Harbor/MiddleandOuterReefsReportNov2015.pdf

DCA (Dial Cordy and Associates Inc.) (2015c) Impact assessment report on hardbottom reef FDEP Final Order \#0305721-001-BI. 2012, PortMiami Phase III Federal Channel Expansion Project. Florida Department of Environmental Protection, Tallahassee.

DCA (Dial Cordy and Associates Inc.) (2015d) Impact Assessment report on middle and outer reef. FDEP Final Order \#0305721-001-BI. 2012, PortMiami Phase III Federal Channel Expansion Project. Florida Department of Environmental Protection, Tallahassee.

DCA (Dial Cordy and Associates, Inc.) (2017) One-year post-construction impact assessment for hardbottom middle and outer reef benthic communities at permanent sites. FDEP Final Order \#0305721-001-BI. 2012. PortMiami Phase III Federal Channel Expansion Project. Florida Department of Environmental Protection, Tallahassee, FL. http://www.saj.usace. army.mil/Portals/44/docs/Planning/EnvironmentalBranch/EnvironmentalDocs/Dade/ PortMiami_Permanent_Site_Report_04_24_17.pdf?ver=2017-05-16-080604-047

DERM (Miami-Dade County Division of Environmental Resources Management) (2016) 24-month monitoring of scleractinians relocated from Government Cut to a natural reef recipient site in association with the Phase 3 Port of Miami/Government Cut deepening project. Resolution R-422-12, Schedule A: Monitoring Project 1. MiamiDade County Department of Regulatory and Economic Resources, Division of Environmental Resources Management (DERM), Restoration and Enhancement Section. [January 2016] 
Diamond D, Toosi H (2020) Trump team failed to follow NSC's pandemic playbook. Politico. https://www.politico.com/news/2020/03/25/trump-coronavirus-national-security-council-149285 [March 25, 2020]

Dobbelaere T, Muller E, Gramer L, Holstein D, Hanert E (2020) Report on the potential origin of the SCTLD in the Florida Reef Tract. Research funded by the Florida Department of Environmental Protection under award PO:B6A24 to Mote Marine Laboratory. https:// floridadep.gov/sites/default/files/report_onset_2014\%20508\%20compliant.pdf

Donahue MZ (2019) Probiotics show promise for coral disease. Smithsonian Institution, National Museum of Natural History. https://naturalhistory.si.edu/research/smithsonian-marine-station/news/probiotics-show-promise-coral-disease

Doss J, Culbertson K, Hahn D, Camacho J, Barekzi N (2017) A review of phage therapy against bacterial pathogens of aquatic and terrestrial organisms. Viruses 9(3): e50. https:// doi.org/10.3390/v9030050

DPNR (Department of Parks and Natural Resources, USVI) (2019) Stony coral tissue loss disease: coral disease with high mortality found on coral reefs on St. Thomas, USVI. https:// dpnr.vi.gov/czm/sctld/

Dubinsky Z, Stambler N (1996) Marine pollution and coral reefs. Global Change Biology 2(6): 511-526. https://doi.org/10.1111/j.1365-2486.1996.tb00064.x

Efrony R, Atad I, Rosenberg E (2009) Phage therapy of coral white plague disease: properties of phage BA3. Current Microbiology 58(2): 139-145. https://doi.org/10.1007/s00284-008-9290-x

Erftemeijer PL, Riegl B, Hoeksema BW, Todd PA (2012) Environmental impacts of dredging and other sediment disturbances on corals: a review. Marine Pollution Bulletin 64(9): 1737-1765. https://doi.org/10.1016/j.marpolbul.2012.05.008

Estrada-Saldıvar N, Molina-Hernández A, Pérez-Cervantes E, Medellın-Maldonado F, González-Barrios FJ, Alvarez-Filip L (2020) Reef-scale impacts of the stony coral tissue loss disease outbreak. Coral Reefs 39: 861-866. https://doi.org/10.1007/s00338-02001949-z

FDEP (Florida Department of Environmental Protection) (2012) Environmental Resource Permit, Miami Harbor Phase III Federal Channel Expansion Project - FDEP Permit No. 0305721-001-BI. https://www.saj.usace.army.mil/Portals/44/docs/Planning/EnvironmentalBranch/EnviroCompliance/Miami\%20Harbor\%20Final\%20Order\%20052212\%20 $508 \% 20$ compliant.pdf

FDEP (Florida Department of Environmental Protection) (2020) Florida Reef Tract Coral Disease Outbreak (2014 - Present). https://floridadep.gov/fco/coral/content/florida-reeftract-coral-disease-outbreak

Finkl CW, Charlier RH (2003) Sustainability of subtropical coastal zones in southeastern Florida: challenges for urbanized coastal environments threatened by development, pollution, water supply, and storm hazards. Journal of Coastal Research 19(4): 934-943.

Finkl CW, Kruempel C (2005) Threats, obstacles and barriers to coastal environmental conservation: societal perceptions and managerial positionalities that defeat sustainable development. Proceedings of the First International Conference on Coastal Conservation and Management in the Atlantic and Mediterranean (ICCCM 05'), 3-28. 
FKNMS (Florida Keys National Marine Sanctuary) (2018) Florida reef tract coral disease outbreak - case definition: stony coral tissue loss disease (SCTLD). https://nmsfloridakeys. blob.core.windows.net/floridakeys-prod/media/docs/20181002-stony-coral-tissue-lossdisease-case-definition.pdf [October 2, 2018]

Fleshler D (2016) South Florida corals dying in "unprecedented" bleaching and disease. South Florida Sun Sentinel. http://www.sunsentinel.com/local/flcoraldying20160424story.html [April 24, 2016]

Fleshler D (2017) Mysterious disease wastes South Florida's corals, and scientists are racing to find a cure. Los Angeles Times. https://www.latimes.com/nation/la-na-florida-corals20171210-story.html [December 10, 2017]

Foster T, Corcoran E, Erftemeijer P, Fletcher C, Peirs K, Dolmans C, Smith A, Yamamoto H, Jury M (2010) Dredging and port construction around coral reefs. PIANC Environmental Commission (No. 108). Report, 1-94. https://www.unep-wcmc.org/resources-and-data/ pianc-dredging-and-port-construction-around-coral-reefs

Giattino C (2020) How epidemiological models of COVID-19 help us estimate the true number of infections. Our World in Data. https://ourworldindata.org/covid-models [August 24, 2020]

Gignoux-Wolfsohn SA, Precht WF, Peters EC, Gintert BE, Kaufman LS (2020) Ecology, histopathology, and microbial ecology of a white-band disease outbreak in the threatened staghorn coral Acropora cervicornis. Diseases of Aquatic Organisms 137(3): 217-237. https:// doi.org/10.3354/dao03441

Gilliam DS, Hayes NK, Ruzicka R, Colella M (2018) Southeast Florida Coral Reef Evaluation and Monitoring Project 2017, Year 15 Executive Summary. Florida DEP Report \#RM143. Miami Beach, 1-15. https://floridadep.gov/sites/default/files/SECREMP2017-Yr15.pdf

Gilliam DS, Walton CJ, Brinkhuis V, Ruzicka R, Colella M (2015) Southeast Florida Coral Reef Evaluation and Monitoring Project 2014 Year 12 Final Report. Florida DEP Report \#RM085. Miami Beach, 1-43. https://floridadep.gov/sites/default/files/SECREMP_2014.pdf

Gilliam DS, Walton CJ, Brinkhuis V, Ruzicka R, Hayes NK (2016) Southeast Florida Coral Reef Evaluation and Monitoring Project 2015, Year 13 Executive Summary. Florida DEP Report \#RM143-. Miami Beach, 1-18. https://floridadep.gov/sites/default/files/SECREMP\%20Year\%2013\%20Executive\%20Summary_Final.pdf

Gintert BE, Precht WF, Fura R, Rogers K, Rice M, Precht LL, D’Alessandro M, Croop J, Vilmar C, Robbart ML (2019) Regional coral disease outbreak overwhelms impacts from a local dredge project. Environmental Monitoring and Assessment 191(10): e630. https:// doi.org/10.1007/s10661-019-7767-7

Gladfelter WB (1982) White-band disease in Acropora palmata: implications for the structure and growth of shallow reefs. Bulletin of Marine Science 32(2): 639-643.

Goodell J (2020) How climate change is ushering in a new pandemic era. Rolling Stone. https://www.rollingstone.com/culture/culture-features/climate-change-risks-infectiousdiseases-covid-19-ebola-dengue-1098923/ [December 7, 2020]

Gottwald TR, Hughes G, Graham, JH, Sun X, Riley T (2001) The citrus canker epidemic in Florida: the scientific basis of regulatory eradication policy for an invasive species. Phytopathology 91(1): 30-34. https://doi.org/10.1094/PHYTO.2001.91.1.30 
Green RH, Smith SR (1997) Sample program design and environmental impact assessment on coral reefs. Proceedings $8^{\text {th }}$ International Coral Reef Symposium, Panama City 2: 1459-1464.

Greer L, Clark T, Waggoner T, Busch J, Guilderson TP, Wirth K, Zhao JX, Curran HA (2020) Coral Gardens Reef, Belize: A refugium in the face of Caribbean-wide Acropora spp. coral decline. PLoS ONE 15(9): e0239267. https://doi.org/10.1371/journal.pone.0239267

Griffin GM (1974) Case history of a typical dredge-fill project in the northern Florida Keys - Effects on water clarity, sedimentation rates and biota. Publication 33, Harbor Branch Foundation, Ft. Pierce, 1-139. http://sunburn.aoml.noaa.gov/general/lib/CEDAR_files/cedar112.pdf

Grigg RW, Dollar S (1995) Doomsday ecology misapplied: alleged versus documented impacts of a deep ocean sewage outfall in Hawaii. In: Ginsburg RN (Ed) Proceedings of the Colloquium on Global Aspects of Coral Reefs, Health, Hazards and History. Atlantic Reef Committee, Univ. of Miami, 333-338.

Hall DG, Gottwald TR (2011) Pest management practices aimed at curtailing citrus huanglongbing disease. Outlooks on Pest Management 22(4): e189. https://doi.org/10.1564/22aug1 1 Hance J (2013) Scientists point to research flaw that has likely exaggerated the impact of logging in tropical forests. Mongabay. https://news.mongabay.com/2013/01/scientists-point-to-researchflaw-that-has-likely-exaggerated-the-impact-of-logging-in-tropical-forests/ [January 23, 2013]

Harvell D, Aronson R, Baron N, Connell J, Dobson A, Ellner S, Gerber L, Kim K, Kuris A, McCallum H, Lafferty K (2004) The rising tide of ocean diseases: unsolved problems and research priorities. Frontiers in Ecology and the Environment 2(7): 75-382. https://doi. org/10.1890/1540-9295(2004)002[0375:TRTOOD]2.0.CO;2

Harvell CD, Mitchell CE, Ward JR, Altizer S, Dobson AP, Ostfeld RS, Samuel MD (2002) Climate warming and disease risks for terrestrial and marine biota. Science 296(5576): 2158-2162. https://doi.org/10.1126/science.1063699

Harvey C (2015) Bleaching and disease are devastating the biggest coral reef in the continental U.S. The Washington Post, Climate and Environment. https:/www.washingtonpost.com/news/ energy-environment/wp/2015/10/26/bleaching-and-disease-are-devastating-the-biggest-coral-reef-in-the-continental-united-states/?utm_term=.f088ea1dafa9 [October 26, 2015]

Hathaway J (2016) Getting past Greenpeace. National Fisherman. https://www.nationalfisherman.com/viewpoints/national-international/getting-past-greenpeace/ [May 16, 2016]

Hayes NK (2019) A characterization of a Southeast Florida stony coral assemblage after a disease event. Master's thesis. Nova Southeastern University. https://nsuworks.nova.edu/occ_stuetd/512 Hayes NK, Walton CJ, Brinkhuis V, Ruzika R, Gilliam DS (2017) SECREMP Southeast Florida Coral Reef Evaluation and Monitoring Project. FDEP-CRCP 2017, Research and Academic Learning Exchange. FDEP - Florida Coastal Office. https://www.youtube.com/ watch?v=3Aj_VIOhJQo\&list=PLraw0H6njzME6cabdw1vRg7 [February 2, 2017]

Hayes RL, Goreau NI (1998) The significance of emerging diseases in the tropical coral reef ecosystem. Revista de Biologia Tropical 46(5): 173-185.

Henderson L, Griffin S, Nemeth M (2019) Stony coral tissue loss disease spreads to the wider Caribbean... and beyond? U.S. National Response Team. https://www.nrt.org/sites/101/ files/VI_SCTLD_CRRT_May2019.pdf [May 2019]

Hobbs J-PA, Frisch AJ, Newman SJ, Wakefield CB (2015) Selective impact of disease on coral communities: outbreak of white syndrome causes significant total mortality of Acropora plate corals. PLoS ONE 10(7): e0132528. https://doi.org/10.1371/journal.pone.0132528 
Hoegh-Guldberg O, Bruno JF (2010) The impact of climate change on the world's marine ecosystems. Science 328(5985): 1523-1528. https://doi.org/10.1126/science.1189930

Iwanowicz D, Schill WB, Woodley CM, Bruckner AW, Neely K, Briggs KM (2020) Exploring the stony coral tissue loss disease bacterial pathobiome. bioRxiv 2020.05.27.120469. https://doi.org/10.1101/2020.05.27.120469

Johns Hopkins University (2020) Coronovirus Resource Center - COVID-19 Case Tracker. https://coronavirus.jhu.edu/data/mortality

Kabay LB, Gilliam DS, Semon-Lunz K (2017) Contributions to the Species Action Plan for the pillar coral, Dendrogyra cylindrus. Research and Academic Learning Exchange, FDEP - Florida Coastal Office. https://www.youtube.com/watch?v=KCk_mxoDX_8 [February 2, 2017]

Kimel E (2018) Coral scientists create gene bank for endangered pillar coral. Herald-Tribune. https://www.heraldtribune.com/news/20180513/coral-scientists-create-gene-bank-forendangered-pillar-coral [May 13, 2018]

Kline DI, Vollmer SV (2011) White Band Disease (type I) of endangered Caribbean acroporid corals is caused by pathogenic bacteria. Scientific Reports 1: 7. https://doi.org/10.1038/srep00007

Kline WN, Duquesnel JG (1996) Management of invasive exotic plants with herbicides in Florida. Down to Earth 51(2): 22-28.

Klingener N (2019) Coral disease prompts unprecedented rescue project in South Florida's waters. WLRN. https://www.wlrn.org/post/coral-disease-prompts-unprecedented-rescueproject-south-floridas-waters [April 1, 2019]

Koh LP, Ghazoul J, Butler RA, Laurance WF, Sodhi NS, Mateo-Vega J, Bradshaw CJ (2010) Wash and spin cycle threats to tropical biodiversity. Biotropica 42(1): 67-71. https://doi. org/10.1111/j.1744-7429.2009.00588.x

Komonen A, Halme P, Kotiaho JS (2019) Alarmist by bad design: strongly popularized unsubstantiated claims undermine credibility of conservation science. Rethinking Ecology 4: 17-19. https://doi.org/10.3897/rethinkingecology.4.34440

Korten T (2015a) In Florida, officials ban term 'climate change.' Miami Herald. https://www. miamiherald.com/news/state/florida/article12983720.html [March 8, 2015]

Korten T (2015b) Gov. Rick Scott's ban on climate change term extended to other state agencies. Miami Herald. https://www.miamiherald.com/news/state/florida/article13576691. html [March 11, 2015]

Kuehn RR (2015) Bias in environmental agency decision making. Environmental Law 45(4): 957-1019. https://www.jstor.org/stable/43799778

Kuntz M (2014) "Parallel science" of NGO advocacy groups: how post-modernism encourages pseudo-science. Genetic Literacy Project. https://www.geneticliteracyproject. org/2014/07/15/parallelscienceofngoadvocacygroupshowpostmodernismencouragespseudoscience/ [July 15, 2014]

Ledford H (2017) Geneticists enlist engineered virus and CRISPR to battle citrus disease. Scientific American - Nature News 545(7654): 277. https://doi.org/10.1038/545277a

Lee S, Hwang C, Moon MJ (2020) Policy learning and crisis policy-making: quadruple-loop learning and COVID-19 responses in South Korea. Policy and Society 39(3): 363-81. https://doi.org/10.1080/14494035.2020.1785195 
Leonhardt D (2020) Trump's role in the death toll - He was warned, again and again. New York Times, Opinion Today. https:/www.nytimes.com/2020/04/13/opinion/coronavirusunited-states-south-korea.html [April 13, 2020]

Lessios HA, Robertson DR, Cubit JD (1984) Spread of Diadema mass mortality throughout the Caribbean. Science 226: 335-337. https://doi.org/10.1126/science.226.4672.335

Lewandowsky S (2011) Attacks on climate scientists are the real 'climategate.' The Guardian. https://www.theguardian.com/environment/blog/2011/nov/23/attacks-climate-scientistsreal-climategate [November 23, 2011]

Lewis C (2016) Pillar Coral (Dendrogyra cylindrus) fragment rescue and relocation for preservation of genetic diversity in the Florida Keys Reef Tract: Dendrogyra rescue blitz. FKNMS2015-156-A1, Report \#1B - 25 October 2016. [May-August 2016]

Lewis CL, Neely KL, Richardson LL, Rodriguez-Lanetty M (2017) Temporal dynamics of black band disease affecting pillar coral (Dendrogyra cylindrus) following two consecutive hyperthermal events on the Florida reef tract. Coral Reefs 36(2): 427-431. https://doi. org/10.1007/s00338-017-1545-1

Lirman D, Schopmeyer S, Manzello D, Gramer LJ, Precht WF, Muller-Karger F, Banks K, Barnes B, Bartels E, Bourque A, Byrne J (2011) Severe 2010 cold-water event caused unprecedented mortality to corals of the Florida reef tract and reversed previous survivorship patterns. PLoS ONE 6(8): e23047. https://doi.org/10.1371/journal.pone.0023047

Livingston J (2020) New York Times exposes coronavirus coverup and incompetence. Medium. https://medium.com/beingwell/new-york-times-exposes-coronavirus-coverup-andincompetence-7e9282195517 [March 13, 2020]

Lu N, Cheng KW, Qamar N, Huang KC, Johnson JA (2020) Weathering COVID-19 storm: successful control measures of five Asian countries. American Journal of Infection Control. 48(7): 851-852. https://doi.org/10.1016/j.ajic.2020.04.021

Lubofsky E (2019) Virgin Island corals in crisis: Fast-spreading coral disease ravages reefs of St. Thomas. Woods Hole Oceanographic Institution. https://www.whoi.edu/news-insights/ content/virgin-island-corals-in-crisis/ [May 7, 2019]

Lunz K, Landsberg J, Kiryu Y, Brinkhuis V (2017) Investigation of the coral disease outbreak affecting scleractinian corals of the Florida reef tract. Florida DEP. Miami, 1-9. https:// floridadep.gov/fco/coral/content/florida-reef-tract-coral-disease-outbreak

Lutcavage M (2016) Environmental bullies: how conservation ideologues attack scientists who don't agree with them. Medium. https://medium.com/@Tuna/environmental-bullies-how-conservation-ideologues-attack-scientists-who-don-t-agree-with-them-8b48e57385bd [March 8, 2016]

Macaluso J (2016) Florida puts bounty on invasive lionfish. The Advocate. https://www. theadvocate.com/baton_rouge/sports/outdoors/article_6beb36cd-47ec-594c-8f42aa72a798a1b7.html [April 20, 2016]

Mann ME, Toles T (2016) The Madhouse Effect: How Climate Change Denial is Threatening our Planet, Destroying our Politics, and Driving us Crazy. Columbia University Press. https:/cup.columbia.edu/book/the-madhouse-effect/9780231177863

Manzello DP (2015) Rapid recent warming of coral reefs in the Florida Keys. Scientific Reports 5: e16762. https://doi.org/10.1038/srep16762 
Marella RL (1998) Water-quality assessment of southern Florida-wastewater discharges and runoff. United States Geological Survey National Water-Quality Assessment Program, USGS Fact Sheet FS-032-98. https://doi.org/10.3133/fs03298

Martin C (2019) A mysterious coral disease is ravaging Caribbean reefs. Science News. https:// www.sciencenews.org/article/mysterious-coral-disease-ravaging-caribbean-reefs [July 9, 2019]

Marszalek DS (1982) Impact of dredging on a subtropical reef community, southeast Florida, U.S.A. Proceedings $4^{\text {th }}$ International Coral Reef Symposium, Manilla 1: 147-153.

Mayfield AB, Tsai S, Lin C (2019) The coral hospital. Biopreservation and Biobanking 17(4): 355-69. https://doi.org/10.1089/bio.2018.0137

Maynard J, Van Hooidonk R, Eakin CM, Puotinen M, Garren M, Williams G, Heron SF, Lamb J, Weil E, Willis B, Harvell CD (2015) Projections of climate conditions that increase coral disease susceptibility and pathogen abundance and virulence. Nature Climate Change 5(7): e688. https://doi.org/10.1038/nclimate2625

Maynard J, Byrne J, Kerrigan K, Tracey D, Bohnsack K, Pagan F, Walczak J, Williams GJ (2017) Coral reef resilience to climate change in the Florida reef tract. Florida Department of Environmental Protection. Miami, 1-30. https:/www.ncei.noaa.gov/data/oceans/coris/ library/NOAA/CRCP/NOS/OCM/Projects/198/NA15NOS4820081/Maynard2017_ Florida_Reef_Resilience.pdf

McCallum HI, Kuris A, Harvell CD, Lafferty KD, Smith GW, Porter J (2004) Does terrestrial epidemiology apply to marine systems?. Trends in Ecology \& Evolution 19(11): 585-91. https://doi.org/10.1016/j.tree.2004.08.009

McGregor G (2020) South Korea amassed the world's most comprehensive coronavirus data. What it's taught us so far. Fortune. https://fortune.com/2020/03/19/coronavirus-southkorea-test-data/ [March 19, 2020]

McNeil DG (2020) Inside China's all-out war on the coronavirus. The New York Times. https:// www.nytimes.com/2020/03/04/health/coronavirus-china-aylward.html [March 4, 2020]

McWilliams JP, Côté IM, Gill JA, Sutherland WJ, Watkinson AR (2005) Accelerating impacts of temperature-induced coral bleaching in the Caribbean. Ecology 86(8): 2055-2060. https://doi.org/10.1890/04-1657

Mera H, Bourne DG (2018) Disentangling causation: complex roles of coral-associated microorganisms in disease. Environmental Microbiology 20(2): 431-449. https://doi. org/10.1111/1462-2920.13958

Merselis DG, Lirman D, Rodriguez-Lanetty M (2018) Symbiotic immuno-suppression: is disease susceptibility the price of bleaching resistance? PeerJ 6: e4494. https://doi. org/10.7717/peerj.4494

Meyer JL, Castellanos-Gell J, Aeby GS, Häse CC, Ushijima B, Paul VJ (2019) Microbial community shifts associated with the ongoing stony coral tissue loss disease outbreak on the Florida ReefTract. Frontiers in Microbiology 10: e2244. https://doi.org/10.3389/fmicb.2019.02244

Miami Waterkeeper (2019) Legal Actions: Protecting Florida’s Coral Reefs from the Impacts of Dredging. https://www.miamiwaterkeeper.org/legal_actions

Miami Waterkeeper (2020) Legal Advocacy. https://www.miamiwaterkeeper.org/legal_advocacy Miller J, Muller E, Rogers C, Waara R, Atkinson A, Whelan KRT, Patterson M, Witcher BE (2009) Coral disease following massive bleaching in 2005 causes $60 \%$ decline in coral cover 
on reefs in the US Virgin Islands. Coral Reefs 28(4): 925-937. https://doi.org/10.1007/ s00338-009-0531-7

Miller JR (2015) Environmental groups collecting millions from federal agencies they sue, studies show. Fox News. https://www.foxnews.com/politics/environmental-groups-collecting-millions-from-federal-agencies-they-sue-studies-show [December 23, 2015]

Miller ME (2012) Port of Miami deep dredge clears final hurdle as environmentalists drop lawsuit. Miami New Times. https://www.miaminewtimes.com/news/port-of-miami-deepdredge-clears-final-hurdle-as-environmentalists-drop-lawsuit-6519362 [April 25, 2012]

Miller MW, Colburn PJ, Pontes E, Williams DE, Bright AJ, Serrano XM, Peters EC (2019) Genotypic variation in disease susceptibility among cultured stocks of elkhorn and staghorn corals. PeerJ 7: e6751. https://doi.org/10.7717/peerj.6751

Miller MW, Karazsia J, Groves CE, Griffin S, Moore T, Wilber P, Gregg K (2016) Detecting sedimentation impacts to coral reefs resulting from dredging the PortMiami, Florida USA. PeerJ 4: e2711. https://doi.org/10.7717/peerj.2711

Miller MW, Precht WF (2013) Climate change impacts on south Florida coral reefs. In: Predicting ecological changes in the Florida Everglades under a future climate scenario, USGS/ CES Meeting, Florida Atlantic University, Boca Raton. http://www.ces.fau.edu/files/projects/climate_change/ecology_february_2013/10_Miller.pdf [February 2013]

Mooney C (2015) Florida officials' 'ban' of the term climate change is straight out of the Bush playbook. Washington Post. https://www.washingtonpost.com/news/energy-environment/wp/2015/03/10/floridas-ban-of-the-term-climate-change-is-straight-out-of-thebush-playbook/ [March 10, 2015]

Morgan C, Wang A (2020) Why South Korea's coronavirus curve looks so different from the United States. Business Insider. https://www.businessinsider.com/south-koreas-coronavirus-curve-timeline-2020-4 [April 16, 2020]

Muller EM, Bartels E, Baums IB (2018) Bleaching causes loss of disease resistance within the threatened coral species Acropora cervicornis. eLife 7:e35066. https://doi.org/10.7554/eLife.35066

Muller EM, Sartor C, Alcaraz NI, van Woesik R (2020) Spatial epidemiology of the stony-coral-tissue-loss disease in Florida. Frontiers Marine Science 7: e163. https://doi.org/10.3389/ fmars.2020.00163

NAS (National Academies of Sciences, Engineering, and Medicine) (2018) A Decision Framework for Interventions to Increase the Persistence and Resilience of Coral Reefs. The National Academies Press, Washington.

NSC (National Security Counsil) (2016) Playbook for Early Response to High-Consequence Emerging Infectious Disease Threats and Biological Incidents. Executive Office of the President, The White House, Washington, 1-69. https://assets.documentcloud.org/documents/6819268/Pandemic-Playbook.pdf

NCRWN (North Central Region Water Network) (2017) The issue of clickbait and exaggeration in environmental journalism. https://northcentralwater.org/the-issue-of-clickbaitand-exaggeration-in-environmental-journalism/ [July 17, 2017]

Neely K (2018) Surveying the Florida Keys southern coral disease boundary. Florida DEP. Miami, 1-15. https://floridadep.gov/sites/default/files/Southern-Coral-Disease-BoundarySurvey-Summary.pdf 
Neely K (2020) Florida Keys coral disease strike team: FY 2019/2020 Final Report. Florida DEP. Miami, 1-17. https://floridadep.gov/rcp/coral/documents/florida-keys-coral-disease-strike-team-fy-19-20-final-report

Neely K, Lewis C (2018) In-situ disease intervention. Florida DEP. Miami, 1-3. https://floridadep.gov/rcp/coral/documents/situ-disease-intervention-june-2018

Neely KL, Lewis C (2020) Rapid population decline of the pillar coral Dendrogyra cylindrus along the Florida reef tract. bioRxiv 2020.05.09.085886. https://doi.org/10.1101/2020.05.09.085886

Neely KL, Macaulay KA, Hower EK, Dobler MA (2020) Effectiveness of topical antibiotics in treating corals affected by stony coral tissue loss disease. PeerJ 8: e9289. https://doi. org/10.7717/peerj.9289

Nelson B (2018) Official letter by Sen. Bill Nelson (FL) from the US Senate Committee on Commerce, Science, and Transportation regarding 'urgency' in solving coral disease crisis in Florida. [February 28, 2018]

Nelson G (2015) NOAA says Port Miami dredge disaster for reef. CBS4 News. https://miami. cbslocal.com/2015/08/18/portmiami-dredge-project-damaging-more-coral-than-expected/ [August 18, 2015]

Newborn S (2019) Coral grown in Tampa Bay helping rescue Florida Keys reefs. WUSF. https://wusfnews.wusf.usf.edu/post/coral-grown-tampa-bay-helping-rescue-florida-keysreefs [April 28, 2019]

NOAA (National Oceanographic and Atmospheric Administration) (2014) 2014 surprisingly rough on coral reefs, and El Niño looms in 2015. https://www.climate.gov/news-features/ featured-images/2014-surprisingly-rough-coral-reefs-and-el-ni\%C3\%B1o-looms-2015

NOAA (National Oceanographic and Atmospheric Administration) (2020) NOAA Strategy for Stony Coral Tissue Loss Disease Response and Prevention. https:/ocmcoralreef.blob.core.windows.net/coralreefprod/media/docs/NOAA_SCTLD_Strategy_2020.pdf [November 24, 2020]

NMFS (National Marine Fisheries Service) (2015) Port of Miami field observations from May 19, 2015. NOAA National Marine Fisheries Service, Southeast Region, West Palm Beach Field Office, 1-19.

NMFS (National Marine Fisheries Service) (2016) Examination of sedimentation impacts to coral reef along the Port of Miami entrance channel, December 2015 - NOAA's National Marine Fisheries Service Final Report, April 2016. Prepared by NOAA National Marine Fisheries Service, Southeast Region, 1-58.

NRR (Natural Resource Report) (2009) Taxpayers foot the bill for environmental lawsuits. https://naturalresourcereport.com/2009/11/taxpayers-foot-the-bill-for-environmentallawsuits/ [November 5, 2009]

NSTC (National Science and Technology Council) (2016) Towards Epidemic Prediction: Federal Efforts and Opportunities in Outbreak Modeling. Report prepared by National Science and Technology Council Committee on Homeland And National Security, Subcommittee on Biological Defense Research and Development Pandemic Prediction and Forecasting Science And Technology Working Group. Executive Office of the President, The White House, Washington, 1-22. https://obamawhitehouse.archives.gov/sites/default/files/microsites/ostp/NSTC/towards_epidemic_prediction-federal_efforts_and_opportunities.pdf [December 2016] 
O'Conner L (2020) Trump says coronavirus will subside in spring, but doctors aren't so sure. HuffPost. https://www.huffpost.com/entry/trump-doctors-coronavirus-prediction_n_5e4 1948dc5b6b70887058c58 [February 11, 2020]

Oh J, Lee JK, Schwarz D, Ratcliffe HL, Markuns JF, Hirschhorn LR (2020) National response to COVID-19 in the Republic of Korea and lessons learned for other countries. Health Systems \& Reform 6(1): e-1753464. https://doi.org/10.1080/23288604.2020.1753464

O’Neil K, Neely K, Patterson J (2018) Nursery management and treatment of disease-ravaged pillar coral (Dendrogyra cylindrus) on the Florida Reef Tract. Florida DEP. Miami, 1-13. https://floridadep.gov/sites/default/files/Copy\%20of\%20Nursery-Management-andTreatment-of-Disease-Ravaged-Pillar-Coral-On-the-FRT.pdf

Orcutt M (2020) If America is at war with COVID-19, it's doing a bad job of fighting. MIT Technology Review. https:/www.technologyreview.com/2020/04/20/1000145/if-america-is-at-war-with-covid-19-doing-a-bad-job-of-fighting/ [April 20, 2020]

Oreskes N, Conway EM (2011) Merchants of Doubt: How a Handful of Scientists Obscured the Truth on Issues from Tobacco Smoke to Global Warming. Bloomsbury Publishing USA.

Parisien A, Allain B, Zhang J, Mandeville R, Lan CQ (2007) Novel alternative to antibiotics: bacteriophages, bacterial cell wall hydrolases, and antimicrobial peptides. Journal of Applied Microbiology 104: 1-13. https://doi.org/10.1111/j.1365-2672.2007.03498.x

Paul VJ, Ushijima B, Aeby G (2019) Studies of the ecology and microbiology of Florida's coral tissue loss diseases. Florida DEP. Miami, 1-33. https://floridadep.gov/rcp/coral/documents/studies-ecology-and-microbiology-floridas-coral-tissue-loss-diseases

Pearce F (2012) Why are environmentalists taking anti-science positions? Yale Environment 360. https://e360.yale.edu/features/why_are_environmentalists_taking_anti-science_positions [October 22, 2012]

Pence M (2020) There Isn't a Coronavirus 'Second Wave.' The White House. https://www. whitehouse.gov/articles/vice-president-mike-pence-op-ed-isnt-coronavirus-second-wave/ [June 16, 2020]

Peters EC (1984) A survey of cellular reactions to environmental stress and disease in Caribbean scleractinian corals. Helgoländer Meeresuntersuchungen 37(1): e113. https://doi. org/10.1007/BF01989298

Peters EC (2015) Diseases of coral reef organisms. In: Birkeland C (Ed.) Coral reefs in the Anthropocene. Springer, Dordrecht, 147-178. https://doi.org/10.1007/978-94-017-7249-5_8

Peters EC, Fogarty ND (2016) Data collection for the Southeast Florida Action Network (SEAFAN) to assess reef conditions before and during the 2014-2015 coral disease outbreak. Florida DEP. Miami, FL. 1-25. https://repository.library.noaa.gov/view/noaa/14351

Plowright RK, Sokolow SH, Gorman ME, Daszak P, Foley JE (2008) Causal inference in disease ecology: investigating ecological drivers of disease emergence. Frontiers in Ecology and the Environment 6(8): 420-429. https://doi.org/10.1890/070086

Pollock FJ, Lamb JB, Field SN, Heron SF, Schaffelke B, Shedrawi G, Bourne DG, Willis BL (2014) Sediment and turbidity associated with offshore dredging increase coral disease prevalence on nearby reefs. PLoS ONE 9(7): e102498. https://doi.org/10.1371/journal.pone.0102498

Pollock FJ, Morris PJ, Willis BL, Bourne DG (2011) The urgent need for robust coral disease diagnostics. PLoS Pathogens 7(10): e1002183. https://doi.org/10.1371/journal.ppat.1002183 
Prasad R (2020) Coronavirus: How did Florida get so badly hit by Covid-19? BBC News. https://www.bbc.com/news/world-us-canada-53357742 [July 13, 2020]

Precht WF (2018) Can coral reefs and large-scale dredging projects coexist? WEDA Dredging Summit \& Expo '18 Proceedings, Norfolk, 214-221. https://www.westerndredging.org/ images/2018/proceedings/4b-2.pdf

Precht WF (2020) Florida's diseased reefs - unprecedented coral disease laying waste to reefs in Florida and the Caribbean. ECO Environment, Coastal and Marine http://digital.ecomagazine. com/publication/frame.php?i=664239\&p=85\&pn=\&ver=html5\&pp=1\&view=issueViewer

Precht WF, Aronson RB (1997) White band disease in the Florida Keys-a continuing concern. Reef Encounter 22: 14-16.

Precht W, Gintert B, Fura R, Precht L, Rogers K, Robbart M (2018) Coral disease ravages reef-building corals throughout Southeast Florida. Inside Ecology. https:/insideecology. com/2018/04/05/coral-disease-ravages-reef-building-corals-throughout-southeast-florida/ [April 5, 2018]

Precht WF, Gintert B, Fura R, Rogers K, Robbart M, Dial S (2019) Miami Harbor deep dredge project: a reappraisal reveals same results. WEDA Dredging Summit \& Expo '19 Proceedings, Chicago. https://www.researchgate.net/profile/William_Precht/publication/333666959_MIAMI_HARBOR_DEEP_DREDGE_PROJECT_A_REAPPRAISAL_REVEALS_SAME_ RESULTS/links/5cfc4f69299bf13a38489202/MIAMI-HARBOR-DEEP-DREDGE-PROJECT-A-REAPPRAISAL-REVEALS-SAME-RESULTS.pdf

Precht WF, Gintert BE, Robbart ML, Fura R, van Woesik R (2016) Unprecedented diseaserelated coral mortality in southeastern Florida. Scientific Reports 6: e31374. https://doi. org/10.1038/srep31374

Precht WF, Miller SL (2007) Ecological shifts along the Florida reef tract: The past as a key to the future. In: Aronson RB (Ed.) Geological Approaches to Coral Reef Ecology. Springer, 237-312.

PTH (Protect the Harvest) (2020) Many environmental NGO's do nothing to actually protect the environment. https://protecttheharvest.com/news/many-environmental-ngos-donothing-to-actually-protect-the-environment/

Quinn C (2020) Pompeo continues the China blame game. ForeignPolicy. https://foreignpolicy.com/2020/05/04/pompeo-continues-china-blame-game/ [May 4, 2020]

Randall CJ, Jordán-Garza AG, Muller EM, van Woesik R (2014) Relationships between the history of thermal stress and the relative risk of diseases of Caribbean corals. Ecology 95: 1981-1994. https://doi.org/10.1890/13-0774.1

Randall CJ, van Woesik R (2017) Some coral diseases track climate oscillations in the Caribbean. Scientific Reports 7(1): e5719. https://doi.org/10.1038/s41598-017-05763-6

Raoult D, Mouffok N, Bitam I, Piarroux R, Drancourt M (2013) Plague: history and contemporary analysis. Journal of Infection 66(1): 18-26. https://doi.org/10.1016/j.jinf.2012.09.010

Raymundo LJ, Burge CA, Lamb JB (2020) Disease ecology in marine conservation and management. In: Behringer DC, Silliman BR, Lafferty KD (Eds) Marine Disease Ecology. Oxford University Press, 159-182. https://doi.org/10.1093/oso/9780198821632.003.0009

Reshef L, Koren O, Loya Y, Zilber-Rosenberg I, Rosenberg E (2006) The coral probiotic hypothesis. Environmental Microbiology 8(12): 2068-2073. https://doi.org/10.1111/ j.1462-2920.2006.01148.x 
Richardson LL, Goldberg WM, Carlton RG, Halas JC (1998a) Coral disease outbreak in the Florida Keys: Plague Type II. Revista de Biologia Tropical 46: 187-198.

Richardson LL, Goldberg WM, Kuta KG, Aronson RB, Smith GW, Ritchie KB, Halas JC, Feingold JS, Miller SL (1998b) Florida's mystery coral-killer identified. Nature 393: 557-558. https://doi.org/10.1038/33302

Ritchie KB (2006) Regulation of microbial populations by coral surface mucus and mucus-associated bacteria. Marine Ecology Progress Series 322: 1-14. https://doi.org/10.3354/meps322001

Rodgers CJ, Furones MD (2009) Antimicrobial agents in aquaculture: practice, needs and issues. Options Méditerranéennes 86: 41-59.

Rogers C (2009) Coral bleaching and disease should not be underestimated as causes of Caribbean coral reef decline. Proceedings of the Royal Society of London B: Biological Sciences 276(1655): 197-198. https://doi.org/10.1098/rspb.2008.0606

Rogers CS, Muller E, Spitzack, T, Miller J (2009) Extensive coral mortality in the US Virgin Islands in 2005/2006: A review of the evidence for synergy among thermal stress, coral bleaching and disease. Caribbean Journal of Science 45: 204-214. https://doi.org/10.18475/cjos.v45i2.a8

Rosales SM, Clark AS, Huebner LK, Ruzicka RR, Muller EM (2020) Rhodobacterales and Rhizobiales are associated with stony coral tissue loss disease and its suspected sources of transmission. Frontiers in Microbiology 11: e681. https://doi.org/10.3389/fmicb.2020.00681

Ruzicka R (2018) Brief overview and preliminary synopsis of coral loss due to the coral disease outbreak in SE FL and Florida Keys - CREMP \& SECREMP results. https://floridadep. gov/fco/coral/content/florida-reef-tract-coral-disease-outbreak

Ruzicka RR, Colella MA, Porter JW, Morrison JM, Kidney JA, Brinkhuis V, Lunz KS, Macaulay KA, Bartlett LA, Meyers MK, Colee J (2013) Temporal changes in benthic assemblages on Florida Keys reefs 11 years after the 1997/1998 El Nińo. Marine Ecology Progress Series 489: 125-141. https://doi.org/10.3354/meps10427

Schneider EC (2020) Failing the test - the tragic data gap undermining the U.S. pandemic response. The New England Journal of Medicine 383:299-302. https://doi.org/10.1056/ NEJMp2014836 [May 15, 2020]

Serbesoff-King K (2003) Melaleuca in Florida: a literature review on the taxonomy, distribution, biology, ecology, economic importance and control measures. Journal of Aquatic Plant Management 41(1): 98-112.

Scheufele DA, Krause NM (2019) Science audiences, misinformation, and fake news. Proceedings of the National Academy of Sciences 116(16):7662-7669. https://doi.org/10.1073/ pnas. 1805871115

Schwarz U (1991) Umweltkonzem im Zwielicht. Geldmachine Greenpeace. Der Spiegel 45(38): 84-105. [September 16, 1991]

Sharp WC, Maxwell KE, Hunt JH (2019) Investigating the ongoing coral disease outbreak in the Florida Keys: Evaluating its small-scale epidemiology and mitigation techniques. Final Report. Florida Department of Environmental Protection,1-34. https://floridadep.gov/rcp/coral/documents/investigating-ongoing-coral-disease-outbreak-florida-keys-evaluating-its-small-0

Sharp WC, Shea CP, Maxwell KE, Muller EM, Hunt JH (2020) Evaluating the small-scale epidemiology of the stony-coral-tissue-loss-disease in the middle Florida Keys. PLoS ONE 15(11): e0241871. https://doi.org/10.1371/journal.pone.0241871 
Shepherd K (2020) Facebook deleted a viral video full of false coronavirus claims. Then Trump shared it on Twitter. The Philadelphia Inquirer. https:/www.inquirer.com/politics/nation/ facebook-false-coronavirus-viral-video-trump-twitter-20200728.html [July 28, 2020]

Sheridan C, Kramarsky-Winter E, Sweet M, Kushmaro A, Leal MC (2013) Diseases in coral aquaculture: causes, implications and preventions. Aquaculture 396: 124-135. https://doi. org/10.1016/j.aquaculture.2013.02.037

Sinigalliano CD, Enochs IC, Stamates SJ, Jones PR, Featherstone CM, Gidley ML, Rosales SM, Gramer LJ, Staley C, Carsey TP (2019) Water quality and coral reef monitoring along the southeast Florida coast. NOAA Technical Report, OAR-AOML-47, 1-145.

Silverstein R (2014) Legal settlement a win for Miami and our bay. Op-Ed, Miami Herald. http://www.miamiherald.com/opinion/op-ed/article3853885.html [November 12, 2014]

Silverstein R (2015) Port expansion damaged unique coral reefs. Op-Ed, Miami Herald. https://www.miamiherald.com/opinion/op-ed/article36067368.html [September 20, 2015]

Simberloff D (2003) Eradication-preventing invasions at the outset. Weed Science 51(2): 247-253. https://doi.org/10.1614/0043-1745(2003)051[0247:EPIATO]2.0.CO;2

Sinclair P (2020) Florida: a history of science denial. Climate Crock. https://climatecrocks. com/2020/07/26/florida-a-history-of-science-denial/ [July 26, 2020]

Smith GC, Cheeseman CL (2002) A mathematical model for the control of diseases in wildlife populations: culling, vaccination and fertility control. Ecological Modelling 150(1-2): 45-53. https://doi.org/10.1016/S0304-3800(01)00471-9

Soffer N, Zaneveld J, Vega Thurber RL (2015) Phage-bacteria network analysis and its implication for the understanding of coral disease. Environmental Microbiology 17(4): 1203-1218. https://doi.org/10.1111/1462-2920.12553

Sokolow SH, Foley P, Foley JE, Hastings A, Richardson LL (2009) Editor's choice: Disease dynamics in marine metapopulations: modelling infectious diseases on coral reefs. Journal of Applied Ecology 46(3): 621-631. https://doi.org/10.1111/j.13652664.2009.01649.x

Solano JJ, Maki DG, Adirim TA, Shih RD, Hennekens CH (2020) Public health strategies contain and mitigate COVID-19: a tale of two democracies. The American Journal of Medicine 133(12): 1365-1366. https://doi.org/10.1016/j.amjmed.2020.08.001

Solomon MB (2011) Environmentalists challenge dredging project at Port of Miami: Petition could delay launch by more than a year. DC Velocity. http://dcvelocity.com/ articles/20111130port_of_miami_dredging_project_challenged/ [November 30, 2011]

Sosnowski MR, Fletcher JD, Daly AM, Rodoni BC, Viljanen-Rollinson SLH (2009) Techniques for the treatment, removal and disposal of host material during programmes for plant pathogen eradication. Plant Pathology 58(4): 621-635. https://doi.org/10.1111/ j.1365-3059.2009.02042.x

Spadafore R, Vollmer S, Precht WF (in press) Multi-variate analysis of the causes of coral mortality using a repeated measure monitoring program: a case study of SCTLD. Frontiers in Marine Science.

Spring KD, Hodell E (2011) Key West Harbor dredging project resource monitoring. Ocean News \& Technology 17(10): 34-35. http://digital.oceannews.com/ publication/?i=89368\&article_id=898768\&view=articleBrowser\&ver=html5\# “issue_id”: 89368,"view":"articleBrowser","article_id":"898768”\} [November/December 2011] 
Staletovich J (2014a) Bay activists warn Corps to clean up dredge. Miami Herald - Environment. http://www.miamiherald.com/news/local/community/miami-dade/article1975948. html [July 17, 2014]

Staletovich J (2014b) Activists sue to stop Government Cut dredge and protect coral. Miami Herald - Environment. http://www.miamiherald.com/news/local/community/miamidade/article2443072.html [October 01, 2014]

Staletovich J (2015a) Biscayne Bay coral at risk from sloppy dredge work. Miami Herald Environment. http:/www.miamiherald.com/news/local/community/miamidade/article9356072.html [February 05, 2015]

Staletovich J (2015b) PortMiami dredge damages more coral than feds expected. Miami Herald - Environment. http://www.miamiherald.com/news/local/environment/article31350266. html [August 17, 2015]

Staletovich J (2016a) Corps says disease, not dredging, hurt PortMiami coral. Miami Herald - Environment. https://www.miamiherald.com/news/local/environment/article577567. html [February 1, 2016]

Staletovich J (2016b) Mud from PortMiami dredge spurred coral dieoff, study finds. Miami Herald - Environment. http://www.miamiherald.com/news/local/environment/article116312178.html [November 21, 2016]

Staletovich J (2017) Miami's sewage is supposed to be pumped offshore but the pipe has sprung a leak. Miami Herald - Environment. https://www.miamiherald.com/news/local/environment/article164655777.html [July 31, 2017]

Staletovich J (2019) Latest chapter in Port Miami dredge: more dead coral. WLRN Radio. https://www.wlrn.org/environment/2019-06-05/latest-chapter-in-port-miami-dredgemore-dead-coral [June 15, 2019]

Staley C, Kaiser T, Gidley ML, Enochs IC, Jones PR, Goodwin KD, Sinigalliano CD, Sadowsky MJ, Chun CL (2017) Differential impacts of land-based sources of pollution on the microbiota of Southeast Florida coral reefs. Applied Environmental Microbiology 83(10): e03378-16. https://doi.org/10.1128/AEM.03378-16

Stoddart J, Jones R, Page C, Marnane M, De Lestang P, Elsdon T (2019) No effect of dredging on the prevalence of coral disease detected during a large dredging program. Marine Pollution Bulletin 140: 353-363. https://doi.org/10.1016/j.marpolbul.2019.01.047

Sweet MJ, Croquer A, Bythell, JC (2014) Experimental antibiotic treatment identifies potential pathogens of white band disease in the endangered Caribbean coral Acropora cervicornis. Proceedings Royal Society B 281: e1788. https://doi.org/10.1098/rspb.2014.0094

Sweet M, Jones R, Bythell J (2012) Coral diseases in aquaria and in nature. Journal of the Marine Biological Association of the United Kingdom 92(4): 791-801. https://doi. org/10.1017/S0025315411001688

Symonds EM, Sinigalliano C, Gidley M, Ahmed W, McQuaig-Ulrich SM, Breitbart M (2016) Faecal pollution along the southeastern coast of Florida and insight into the use of pepper mild mottle virus as an indicator. Journal of Applied Microbiology 121(5): 1469-1481. https://doi.org/10.1111/jam.13252

Talbot R (2019) As disease ravages coral reefs, scientists scramble for solutions. Yale Environment 360. https://e360.yale.edu/features/as-disease-ravages-coral-reefs-scientists-scramble-for-solutions [January 10, 2019] 
The Guardian (2015) Florida employee 'punished for using phrase climate change'. https:// www.theguardian.com/environment $/ 2015 / \mathrm{mar} / 19 /$ florida-employee-forced-on-leave-climate-change [March 19, 2015]

Teplitski M, Ritchie K (2009) How feasible is the biological control of coral diseases? Trends in Ecology \& Evolution 24(7): 378-385. https://doi.org/10.1016/j.tree.2009.02.008

Thaler AD, Shiffman D (2015) Fish tales: combating fake science in popular media. Ocean \& Coastal Management 115: 88-91. https://doi.org/10.1016/j.ocecoaman.2015.04.005

The Daily Herald (2018) Epidemic disease detected on St. Maarten's coral reefs. https://www. thedailyherald.sx/islands/82937-epidemic-diseasedetected-on-st-maarten-s-coral-reefs [November 25, 2018]

The Maritime Executive (2012) Environmentalists drop lawsuit against Port of Miami deep dredge. https://www.maritime-executive.com/article/environmentalists-drop-lawsuitagainst-port-of-miami-deep-dredge [November 19, 2012]

The Virgin Islands Daily News (2020) Coral World and UVI teaming up to save corals. http:// www.virginislandsdailynews.com/news/coral-world-and-uvi-teaming-up-to-save-corals/ article_85b5d3f7-c676-5ad8-97e5-d3756a85edae.html [August 11, 2020]

Toth LT, Stathakopoulos A, Kuffner IB, Ruzicka RR, Collela MA, Shinn EA (2019) The unprecedented loss of Florida's reef-building corals and the emergence of a novel coral-reef assemblage. Ecology 100(9): e02781. https://doi.org/10.1002/ecy.2781

Townsend A (2019a) The responsibility of truth: just the facts. International Dredging Review 38(5): 5-5. [19.] https://www.dredgemagonline.com/NovDec-2019/1/

Townsend A (2019b) Firm responsible for Miami Harbor deepening project coral monitoring stands by its data and results. The Waterways Journal https://www.waterwaysjournal. net/2019/11/06/firm-responsible-for-miami-harbor-deepening-project-coral-monitoringstands-by-its-data-and-results/

Urry A (2018) Scientists race to decode disease devastating Florida coral reefs. News Deeply. https:/www.newsdeeply.com/oceans/articles/2018/05/16/scientists-race-to-decode-disease-devastating-florida-coral-reefs [May 16, 2018]

Urry A (2019) Scientists are putting antibiotics into the ocean-on purpose. And it's our only hope. MSN News - Popular Science. https://www.msn.com/en-us/news/technology/ scientists-are-putting-antibiotics-into-the-ocean-on-purpose-and-it-s-our-only-hope/arAACM5Gi\#page=2 [June 16, 2019]

Ushijima B, Meyer JL, Thompson S, Pitts K, Marusich MF, Tittl J, Weatherup E, Reu J, Wetzell R, Aeby GS, Häse CC (2020) Disease diagnostics and potential coinfections by Vibrio coralliilyticus during an ongoing coral disease outbreak in Florida. Frontiers in Microbiology 11: e569354. https://doi.org/10.3389/fmicb.2020.569354

van Oppen MJ, Gates RD (2006) Conservation genetics and the resilience of reef-building corals. Molecular Ecology 13: 3863-3883. https://doi.org/10.1111/j.1365-294X.2006.03026.x

van Oppen MJ, Oliver JK, Putnam HM, Gates RD (2015) Building coral reef resilience through assisted evolution. Proceedings of the National Academy of Sciences. 112(8): 2307-13. https://doi.org/10.1073/pnas.1422301112

Vega Thurber RL, Burkepile DE, Fuchs C, Shantz AA, McMinds R, Zaneveld JR (2014) Chronic nutrient enrichment increases prevalence and severity of coral disease and bleaching. Global Change Biology 20(2):544-54. https://doi.org/10.1111/gcb.12450 
Vega Thurber RL, Mydlarz LD, Brandt M, Harvell D, Weil E, Raymundo L, Willis BL, Langevin S, Tracy AM, Littman R, Kemp KM, Dawkins P, Prager KC, Garren M, Lamb J (2020) Deciphering coral disease dynamics: integrating host, microbiome, and the changing environment. Frontiers Ecology and Evolution 8: e575927. https://doi.org/10.3389/fevo.2020.575927

Vizcaino MI, Johnson WR, Kimes NE, Williams K, Torralba M, Nelson KE, Smith GW, Weil E, Moeller PD, Morris PJ (2010) Antimicrobial resistance of the coral pathogen Vibrio coralliilyticus and Caribbean sister phylotypes isolated from a diseased octocoral. Microbial Ecology 59(4): 646-657. https://doi.org/10.1007/s00248-010-9644-3

Vollmer SV, Kline DI (2008) Natural disease resistance in threatened staghorn corals. PLoS ONE 3(11): e3718. https://doi.org/10.1371/journal.pone.0003718

Walker B (2018) Southeast Florida reef-wide post-Irma coral disease surveys. Florida DEP. Miami, 1-45. https://floridadep.gov/fco/coral/documents/southeast-florida-reef-widepost-irma-coral-disease-surveys

Walker B, Brunelle A (2018) Southeast Florida large (>2 m) diseased coral colony intervention summary report. Florida DEP \& FWC. Miami, 1-164 pp. https://nsuworks.nova.edu/cgi/ viewcontent.cgi?article $=1125 \&$ context=occ_facreports $/$

Walker BK, Gilliam DS, Dodge RE, Walczak J (2012) Dredging and shipping impacts on southeast Florida coral reefs. Proceedings of the $12^{\text {th }}$ International Coral Reef Symposium, Cairns https://nsuworks.nova.edu/occ_facpresentations/45/

Walton CJ, Hayes NK, Gilliam DS (2018) Impacts of a regional, multi-year, multi-species coral disease outbreak in Southeast Florida. Frontiers in Marine Science 5: e323. https:// doi.org/10.3389/fmars.2018.00323

Warrender T, Precht W, Olynik J, Chin P, Walton R, Montieth I, Austin T (in press) Emergency salvage and restoration of the pillar coral, Dendrogyra cylindrus (Ehrenberg, 1834) in response to a catastrophic disease outbreak in Grand Cayman, B.W.I. Frontiers in Marine Science.

Wear SL, Vega Thurber RL (2015) Sewage pollution: mitigation is key for coral reef stewardship. Annals of the New York Academy of Sciences 1355(1): 15-30. https://doi.org/10.1111/ nyas. 12785

Weekman K (2017) Florida government pays bounty hunters to capture pythons. AOL.com News. https://www.aol.com/article/news/2017/05/16/florida-government-pays-bountyhunters-to-capture-pythons/22093415/ [May 16, 2017]

Woolf SH, Chapman DA, Sabo RT, Weinberger DM, Hill L, Taylor DD (2020) Excess deaths from COVID-19 and other causes, March-July 2020. Journal American Medical Association 324(15): 1562-1564. https://jamanetwork.com/journals/jama/fullarticle/2771761

Zeller P (2017) After being sued for defamation, Greenpeace admits its claims are hyperbole and not factual. Center of the American Experiment - Energy, Environment. https://www. americanexperiment.org/2017/03/sued-defamation-greenpeace-admits-claims-hyperbolenot-factual/ [March 27, 2017]

Zenko M (2020) The coronavirus is the worst intelligence failure in U.S. history. Foreign Policy. https://foreignpolicy.com/2020/03/25/coronavirus-worst-intelligence-failure-ushistory-covid-19/ [March 25, 2020]

Zvuloni A, Artzy-Randrup Y, Katriel G, Loya Y, Stone L (2015) Modeling the impact of white-plague coral disease in climate change scenarios. PLoS Computational Biology 11: e1004151. https://doi.org/10.1371/journal.pcbi.1004151 